Research article

urn:1sid:zoobank.org:pub:F4F9AFF3-C4D3-4BFE-B4C8-516C14758DAE

\title{
Glaciambulata neumayeri gen. et sp. nov., a new Antarctic trachymedusa (Cnidaria: Hydrozoa), with a revision of the family Ptychogastriidae
}

\author{
Horia R. GALEA ${ }^{1}$, Cornelia RODER ${ }^{2}$, Christoph WALCHER ${ }^{3}$, Marco WARMUTH ${ }^{4}$, \\ Eberhard KOHLBERG ${ }^{5}$ \& Philipp F. FISCHER ${ }^{6, *}$ \\ ${ }^{1}$ Hydrozoan Research Laboratory, 405 Chemin des Gatiers, 83170 Tourves, France. \\ 2,3,4,6 Alfred-Wegener-Institut, Helmholtz Center for Polar and Marine Research \\ Centre for Scientific Diving, Am Binnenhafen 1117, 27498 Helgoland, Germany. \\ ${ }^{5}$ Alfred-Wegener-Institut, Helmholtz Center for Polar and Marine Research, \\ Am Handelshafen 12, 27570 Bremerhaven, Germany. \\ ${ }^{1}$ Email: horia.galea@gmail.com \\ ${ }^{2}$ Email: cornelia.roder@awi.de \\ ${ }^{3}$ Email: Christoph.Walcher@awi.de \\ ${ }^{4}$ Email: Marco.Warmuth@awi.de \\ ${ }^{5}$ Email: eberhard.kohlberg@awi.de \\ *Corresponding author: Philipp.Fischer@awi.de

\footnotetext{
${ }^{1}$ urn:1sid:zoobank.org:author:DE5AC672-0243-46F2-A910-AFF4E91A4C5D

${ }^{2}$ urn:Isid:zoobank.org:author:C64A5D45-0F91-4910-BEEB-3D8B6B360F5A

${ }^{3}$ urn:1sid:zoobank.org:author:D43A2B98-C443-45C6-B610-E0303F04BB43

${ }^{4}$ urn:1sid:zoobank.org:author:65AA01D3-02C0-4395-83E1-B3AABC6F8A6B

${ }^{5}$ urn:1sid:zoobank.org:author:1B33E9B2-B721-4276-A67A-A5A32B45992C

${ }^{6}$ urn:1sid:zoobank.org:author:62F29FDB-3EE2-4922-949D-8BFF889DD205
}

\begin{abstract}
A new genus and species of sympagic trachymedusa, Glaciambulata neumayeri gen. et sp. nov., are described based on material from Antarctica. Its generic features are compared to those of its relatives, Ptychogastria Allman, 1878 and Tesserogastria Beyer, 1959, and a review of the family Ptychogastriidae Mayer, 1910, based on literature data, is provided. From this, it results that the poorlyknown Pectis antarctica Haeckel, 1879, formerly assigned to Ptychogastria by a number of authors, displays all characters of the contemporary rhopalonematid genus Voragonema Naumov, 1971. It is additionally demonstrated that $V$. laciniata Bouillon et al., 2001 is coterminous with $P$. antarctica, a finding that clarifies, 137 years later, the morphology and the taxonomic status of Haeckel's medusa. In accordance with the Principle of Priority, Pectis is recognized as the valid name of the genus, and Voragonema is assigned to its synonymy. Similarly so, the specific name introduced by Haeckel has priority over laciniata.
\end{abstract}

Keywords. Trachymedusae, Rhopalonematidae, hydromedusa, sympagic, Atka Bay. 
Galea H.R., Roder C., Walcher C., Warmuth M., Kohlberg E. \& Fischer P.F. 2016. Glaciambulata neumayeri gen. et sp. nov., a new Antarctic trachymedusa (Cnidaria: Hydrozoa), with a revision of the family Ptychogastriidae European Journal of Taxonomy 252: 1-30. http://dx.doi.org/10.5852/ejt.2016.252

\section{Introduction}

The sub-ice platelet layer is a three-dimensional habitat formed through the continuous accumulation of individual ice crystals below solid sea ice. It is typically found in coastal regions of Antarctica, and is a common phenomenon associated with land-fast sea ice attached to ice shelves (Langhorne et al. 2015). The sub-ice platelet layer is a site of high primary production, with algae and bacteria densely inhabiting the interstitial water and the large surface areas provided by the platelets themselves. This biota is considered as an important food source for the associated pelagic species, but also for the benthic community on the continental shelf, after its disintegration towards the austral summer. The existence of any higher sessile life forms in the sub-ice platelet layers of Antarctica has not yet been documented. During an expedition to Antarctica in the austral summer 2014-2015, the scientific diving team of the Alfred Wegener Institute (AWI), Helmholtz Centre for Polar and Marine Research, accidentally encountered a peculiar hydromedusa settling as inverse benthos on the disks of the sub-ice platelet layer in Atka Bay, close to the research station Neumayer III. The average density of these individuals at that time was less than $1 / 100 \mathrm{~m}^{2}$. An intensive internet search did not reveal any similar observations at this or other sites with a sub-ice platelet layer in the area. Unfortunately, due to weather and legal constraints, it was not possible to take samples for species identification, and a second expedition was organized in the following season (2015-2016), during which numerous samples were collected.

An examination of the available material revealed that we were dealing with an undescribed genus and species of ptychogastriid medusa. The present study aims to describe in detail the morphology of this new animal, by placing it in the context of its family, and by discussing its relationships with the related genera. A review of the family Ptychogastriidae Mayer, 1910, focusing on the reevaluation of the taxonomic status of all genera and species included in it, proved necessary, as well as the emendation of some of the available diagnoses, ranging from genus to order levels within the subclass Trachylinae Haeckel, 1879.

\section{Material and methods}

Scientific research and sampling were approved by the German Federal Environmental Agency under the reference number 94003-3/357. Samples were collected in the frame of the PIA-Project conducted during the expedition ANT-LAND 2015-2016 in Atka Bay, eastern Weddell Sea. The sampling site was located on the land-fast sea ice, about $17 \mathrm{~km}$ North of the German Antarctic Station Neumayer III, which served as the base station for the diving operations. Using the coordinates of the dives undertaken in 2014-2015, two dive holes of ca $2 \times 2 \mathrm{~m}$ were opened in the $3 \mathrm{~m}$ thick sea-ice using chain saws and crow bars. The subjacent, about $5 \mathrm{~m}$ thick and compact, sub-ice platelet layer was removed layer by layer, so that the single platelets coming to the surface could be visually scanned for attached medusae. If platelets with individuals were detected, they were carefully transferred into containers filled with seawater at ambient temperature. Once both the entrance and the emergency dive holes were opened, additional samples were collected directly from the sub-ice platelet layer by SCUBA. All dives were conducted according to the German regulations for Scientific Diving BGR/GUV-R 2112.

All samples for classical taxonomic approaches were fixed in buffered formalin-seawater to a final concentration of $4 \%$, while those for molecular studies (not performed herein) were fixed with absolute ethanol (Applichem). 
GALEA H.R. et al., Glaciambulata neumayeri gen. et sp. nov., a new Antarctic trachymedusa

In situ pictures (Fig. 1A-B) were taken as still frames from video footage recorded with a Sony HDR-XR520VE camera. Pictures ex situ were taken either with a Canon PowerShot G10 (Fig. 1C) or a Canon EOS 60D (Figs 1D-G, 2A-B, E-I), the latter mounted on a Huvitz HSZ-TR30 trinocular stereomicroscope. Photomicrographs (Fig. 2C-D, J-L) were taken using a Tucsen IS1000 CMOS (10 Mpixel) camera mounted on an Optika B-500 trinocular compound microscope.

Nematocyst discharge was artificially induced in fixed specimens by treatment of the tentacles with a $2 \%$ solution of domestic bleach, for 20 seconds, followed by a thorough rinse in tap water. The line drawings were made as described by Galea (2007). The material was deposited in collections of the Muséum d'Histoire Naturelle of Geneva, Switzerland, and registration codes are indicated by MHNGINVE- followed by five-digit numbers.

\section{Results}

Class Hydrozoa Owen, 1843

Subclass Trachylinae Haeckel, 1879

Order Trachymedusae Haeckel, 1866

\section{Diagnosis}

Hydromedusae with umbrella margin entire, not deeply-lobed; with conspicuous marginal nematocyst ring; manubrium with or without gastric peduncle; with circular and radial canals, and gonads usually confined to the latter; centripetal canals either present or absent; tentacles marginal, either solid, or solid and hollow occurring simultaneously; statocysts of ecto-endodermal origin, either free or enclosed; velum generally well-developed, exceptionally absent.

\section{Remarks}

The diagnosis given above combines those provided by Kramp (1968) and Bouillon et al. (2006), and adds the case when the velum is absent, as it will be shown below for the genus Glaciambulata gen. nov.

The taxonomic status of some of the families included in Trachymedusae is unsettled yet. For example, Collins et al. (2008) have shown that the family Geryoniidae Eschscholtz, 1829 is derived from within another order, Limnomedusae Kramp, 1938, and the family Halicreatidae Fewkes, 1886 belongs to a sister group of a clade containing the orders Narcomedusae Haeckel, 1879 and Actinulida Swedmark \& Teissier, 1959, as well as the trachymedusan family Rhopalonematidae Russell, 1953. In addition, according to the same source, some characters of the family Petasidae Haeckel, 1879, especially the presence of 4 radial canals instead of generally 8, common to Rhopalonematidae, suggest that it may belong elsewhere.

Family Ptychogastriidae Mayer, 1910

\section{Diagnosis}

Trachymedusae with either flat or dome-shaped umbrella; with four-lobed manubrium, not giving rise to mesenteries, or with eight-lobed manubrium, giving rise to eight mesenterial partitions of the subumbrella; without gastric peduncle; mouth with four simple lips; tentacles marginal, either filiform, not arranged in groups and inserted at varied levels on the umbrellar margin, or filiform and adhesive occurring simultaneously, and grouped into more or less well-defined clusters composed of several superimposed rows; eight radial canals joining the circular canal; centripetal canals either absent or present; gonads either simple, elongated and attached to the body of manubrium, or in pairs resulting 
from the mesenterial partitions and developing on either side of the manubrial lobes; with or without a velum; with either 8 or 16 free, ecto-endodermal statocysts.

\section{Remarks}

Earlier diagnoses (Mayer 1910; Kramp 1959, 1961, 1968; Bouillon \& Boero 2000; Bouillon et al. 2006) are broadened by taking into consideration the shape of the umbrella, the presence/absence of a velum, and of centripetal canals. Indeed, unlike both Ptychogastria Allman, 1878 and Tesserogastria Beyer, 1959, the medusae belonging to the so far monotypic genus Glaciambulata gen. nov. (see below) have flattened rather than dome-shaped umbrellas, and they also lack a velum. The presence of centripetal canals was curiously excluded from earlier diagnoses of the family, though they are present in P. polaris Allman, 1878. The occurrence of the gonads is henceforth restricted to the manubrium only, because Pectis antarctica Haeckel, 1879, formerly assigned to the genus Ptychogastria by a number of authors, has the gonads on the radial canals and, for this reason, combined with additional characters, does not belong to Ptychogastriidae (see below).

The main distinguishing characters of ptychogastriid genera are listed in Table 1.

Table 1. Main distinguishing characters of the genera belonging to the family Ptychogastriidae Mayer, 1900.

\begin{tabular}{|c|c|c|c|}
\hline & Glaciambulata gen. nov. & $\begin{array}{l}\text { Ptychogastria } \\
\text { Allman, } 1878 \\
\end{array}$ & $\begin{array}{c}\text { Tesserogastria } \\
\text { Beyer, } 1959\end{array}$ \\
\hline Umbrella & Flat & Dome-shaped & Dome-shaped \\
\hline Manubrium & Eight-lobed & Eight-lobed & Four-lobed \\
\hline Mesenteries & 8 & 8 & Absent \\
\hline Tentacles & $\begin{array}{l}\text { Filiform + adhesive; } \\
\text { forming contiguous } \\
\text { groups; inserted in } \\
\text { superimposed rows on } \\
\text { umbrella margin }\end{array}$ & $\begin{array}{l}\text { Filiform + adhesive; } \\
\text { forming contiguous } \\
\text { groups; inserted in } \\
\text { superimposed rows on } \\
\text { umbrella margin }\end{array}$ & $\begin{array}{l}\text { Filiform; reportedly } \\
\text { not arranged in groups; } \\
\text { inserted at varied levels on } \\
\text { umbrella margin }\end{array}$ \\
\hline Centripetal canals & Absent & Present/absent & Absent \\
\hline Gonads & $\begin{array}{l}\text { Ovoid; in pairs, on either } \\
\text { side of the manubrial lobes }\end{array}$ & $\begin{array}{l}\text { Ovoid; in pairs, on either } \\
\text { side of the manubrial lobes }\end{array}$ & $\begin{array}{l}\text { Elongated; simple; } \\
\text { attached to the body of } \\
\text { manubrium }\end{array}$ \\
\hline Velum & Absent & Present & Present \\
\hline Statocysts & 16 & 16 & 8 \\
\hline Ability to swim & No & Yes & Yes \\
\hline
\end{tabular}

\section{Key to the genera}

1. Tentacles exclusively filiform Tesserogastria Beyer, 1959

- Tentacles of two types: filiform and adhesive

2. Umbrella dome-shaped, velum present

Ptychogastria Allman, 1878

- Umbrella flat, velum absent Glaciambulata gen. nov. 
GALEA H.R. et al., Glaciambulata neumayeri gen. et sp. nov., a new Antarctic trachymedusa

Genus Glaciambulata Galea, gen. nov. urn:Isid:zoobank.org:act:B2696364-D58F-4BB9-B326-DE244E1FA51A

\section{Type species}

Glaciambulata neumayeri gen. et sp. nov.

\section{Diagnosis}

Crawling medusae, unable to swim, possibly due to the absence of a velum. Umbrella watch glassshaped, margin entire, not lobed; exumbrella smooth; eight radial canals joining a circular canal; centripetal canals absent; manubrium eight-lobed, giving rise to eight perradial mesenteries; eight pairs of gonads, each of which is confined to either side of a manubrial lobe; tentacles of two types, filiform and adhesive, arranged in contiguous groups composed of several superimposed rows; 16 free, ectoendodermal statocysts ( 2 per octant).

\section{Etymology}

From the Latin words glăciess, meaning ice, and ambŭlo, - $\bar{a} v \bar{v},-\bar{a} t u m,-\bar{a} r e$, meaning to walk, making reference to the peculiar habit of this medusa.

\section{Remarks}

The flat, smooth umbrella, and the absence of a velum immediately distinguish the new genus from Ptychogastria Allman, 1878 and Tesserogastria Beyer, 1959. The manubrial shape, the composition and arrangement of tentacles, the presence of mesenteries, and the shape and position of the gonads, are reminiscent of Ptychogastria. The presence of adhesive tentacles, and of 16 statocysts, instead of only 8 , further distinguish it from Tesserogastria.

Glaciambulata neumayeri Galea, Roder, Walcher, Warmuth, Kohlberg \& Fischer, gen. et sp. nov. urn:1sid:zoobank.org:act:9DBB7DC2-6BEB-42DF-BFCB-0A3B0193AB41

Figs $1-3$

\section{Diagnosis}

As for the genus.

\section{Etymology}

The species is named after the German Antarctic Station Neumayer III, the platform for all diving operations, from the vicinity of which the new medusa was discovered.

\section{Material examined}

\section{Holotype}

ANTARCTICA: $\widehat{\partial}$, umbrella $(\mathrm{U})=6 \mathrm{~mm}$ wide, total diameter of medusa (D) from tip to tip of opposite tentacles $=17 \mathrm{~mm}$, Atka Bay, 7-9 m, -70.533, -8.055, 12 Dec. 2015 (MHNG-INVE-93880), the medusa was attached to the last, hence youngest, stratum of the sub-ice platelet layer.

Paratypes (station data as for holotype)

ANTARCTICA: 1 $\widehat{\jmath}, \mathrm{U}=4 \mathrm{~mm}, \mathrm{D}=12 \mathrm{~mm}, 7-9 \mathrm{~m}, 12$ Dec. 2015 (MHNG-INVE-93881); 2 medusae [o+: $\mathrm{U}=5 \mathrm{~mm}, \mathrm{D}=16 \mathrm{~mm}$; $\widehat{O}^{\top}: \mathrm{U}=4 \mathrm{~mm}, \mathrm{D}=$ not available (N.A.)], $0 \mathrm{~m}, 18$ Dec. 2015 (MHNGINVE-93882); 2 medusae (: $\mathrm{U}=4.5 \mathrm{~mm}, \mathrm{D}=19 \mathrm{~mm}$; $\circ: \mathrm{U}=4 \mathrm{~mm}, \mathrm{D}=$ N.A.), $12 \mathrm{~m}, 18$ Dec. 2015 (MHNG-INVE-93883); 2 medusae ( $\left(\right.$ : $\left.\mathrm{U}=5 \mathrm{~mm}, \mathrm{D}=15 \mathrm{~mm} ; \mathrm{O}^{\lambda}: \mathrm{U}=4 \mathrm{~mm}, \mathrm{D}=\mathrm{N} . \mathrm{A}.\right), 23 \mathrm{~m}$, 18 Dec. 2015 (MHNG-INVE-93884); two medusae ( $\sigma^{\lambda}: \mathrm{U}=4 \mathrm{~mm}, \mathrm{D}=12 \mathrm{~mm} ; \hat{\partial}: \mathrm{U}=3 \mathrm{~mm}, \mathrm{D}=$ $10 \mathrm{~mm}$ ), $5 \mathrm{~m}, 24$ Dec. 2015 (MHNG-INVE-93886); 1 क medusa $(\mathrm{U}=4 \mathrm{~mm}, \mathrm{D}=12 \mathrm{~mm}), 25 \mathrm{~m}, 24$ Dec. 2015 (MHNG-INVE-93885); 1 क medusa $(\mathrm{U}=5 \mathrm{~mm}, \mathrm{D}=16 \mathrm{~mm}), 25 \mathrm{~m}, 27$ Dec. 2015 (MHNGINVE-93887). 

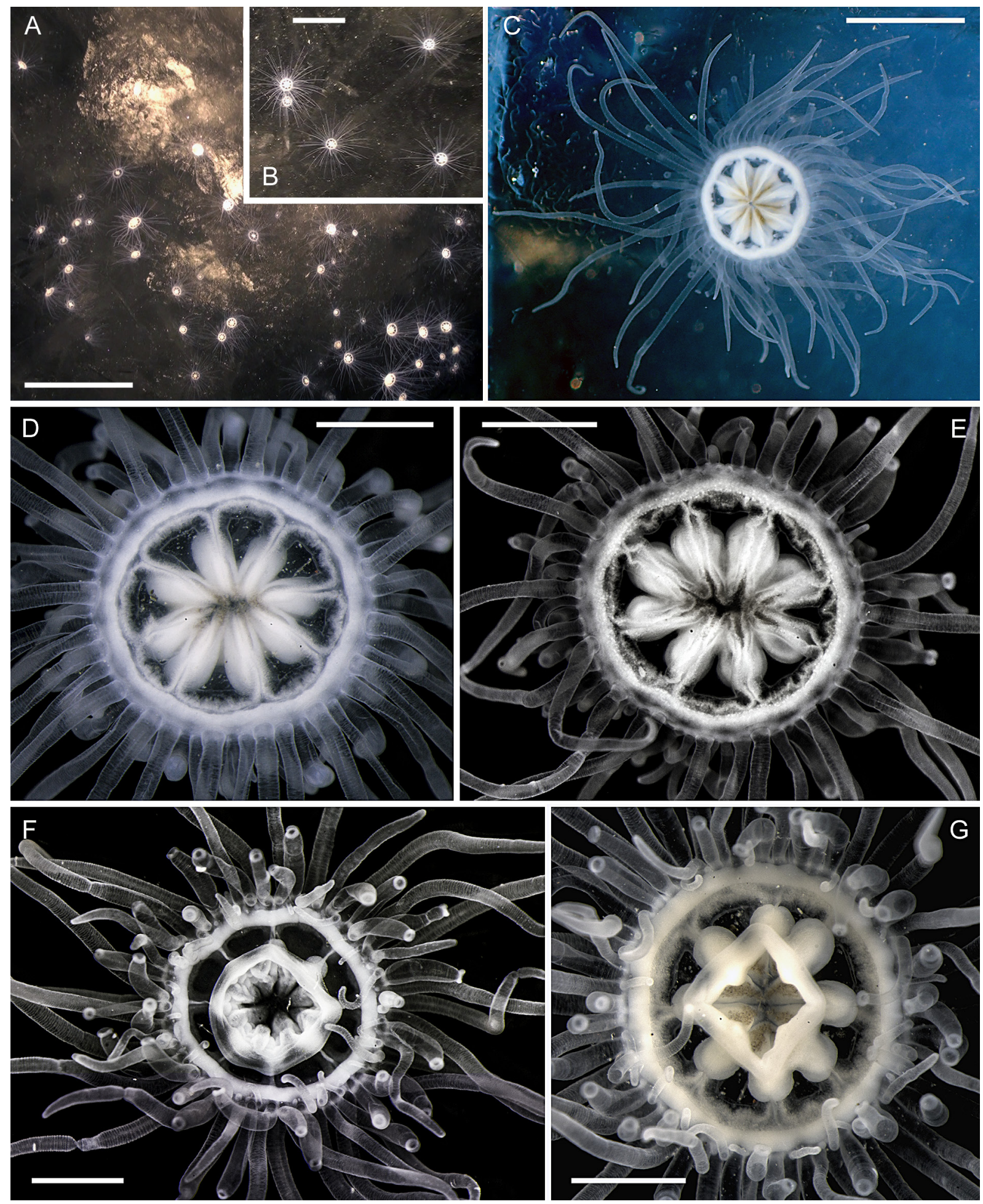

Fig. 1. Glaciambulata neumayeri Galea, Roder, Walcher, Warmuth, Kohlberg \& Fischer, gen. et sp. nov. A-C. Living medusae. D-G. Preserved medusae in aboral (D, E) and oral (F, G) views. Scale bars: A, $\mathrm{C}=5 \mathrm{~mm} ; \mathrm{B}, \mathrm{D}-\mathrm{G}=2 \mathrm{~mm}$. 

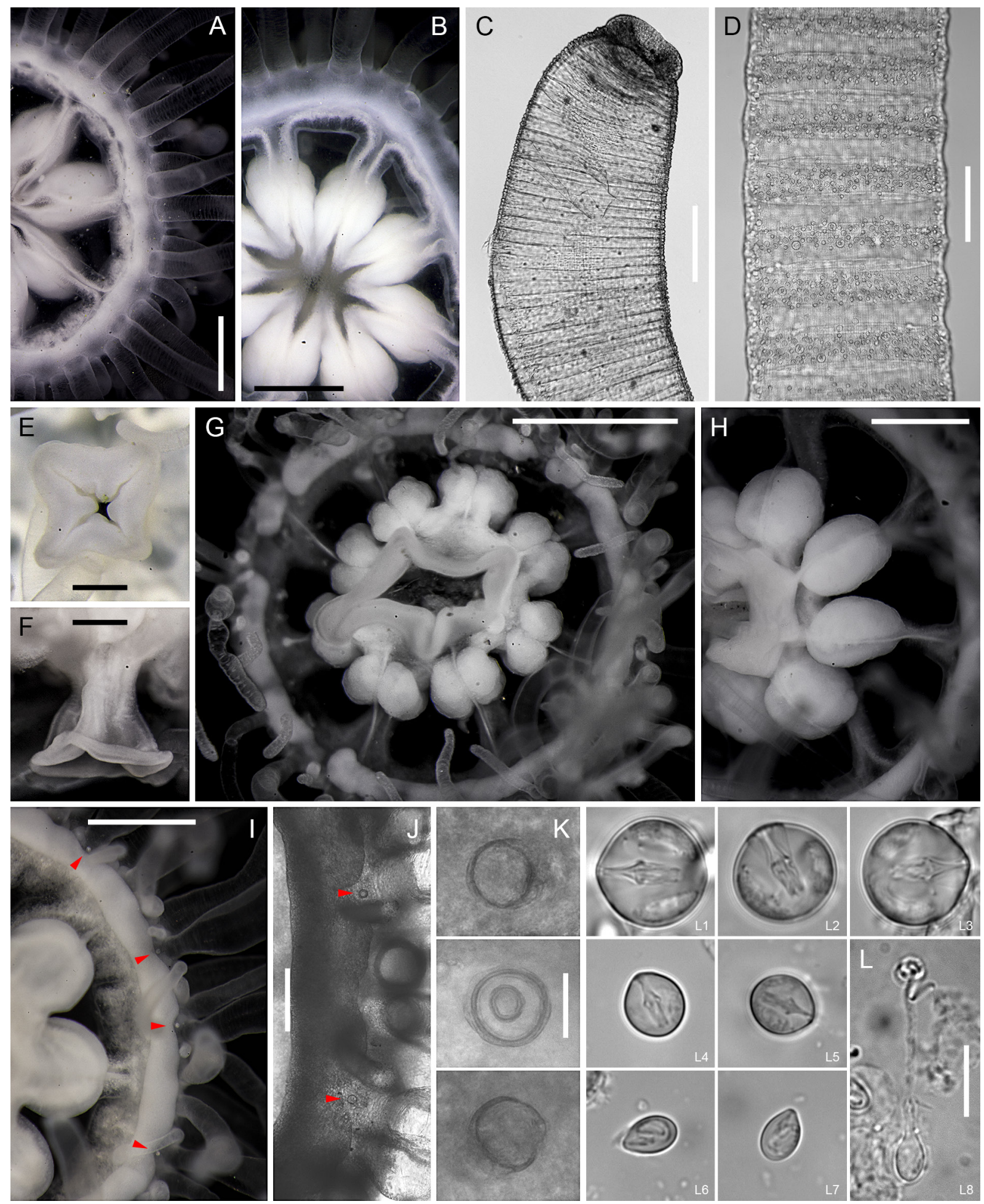

Fig. 2. Glaciambulata neumayeri Galea, Roder, Walcher, Warmuth, Kohlberg \& Fischer, gen. et sp. nov. A. Arrangement pattern of the large, filiform tentacles around the bell margin. B. Aboral view of a medusa showing some radial and the ring canal. C. Distal part of an adhesive tentacle. D. Portion of a filiform tentacle, showing the arrangement of the nematocysts. E-F. The mouth in frontal (E) and lateral (F) aspects. G-H. Arrangement and structure of the gonads. I-J. Position of the statocysts (arrowheads). K. Close-ups of three statocysts. L. Cnidome. Scale bars: $\mathrm{G}=2 \mathrm{~mm}$; A, B, H, I = $1 \mathrm{~mm} ; \mathrm{E}, \mathrm{F}=500 \mu \mathrm{m}$; $\mathrm{C}, \mathrm{J}=200 \mu \mathrm{m} ; \mathrm{K}=30 \mu \mathrm{m} ; \mathrm{L}=10 \mu \mathrm{m}$. 


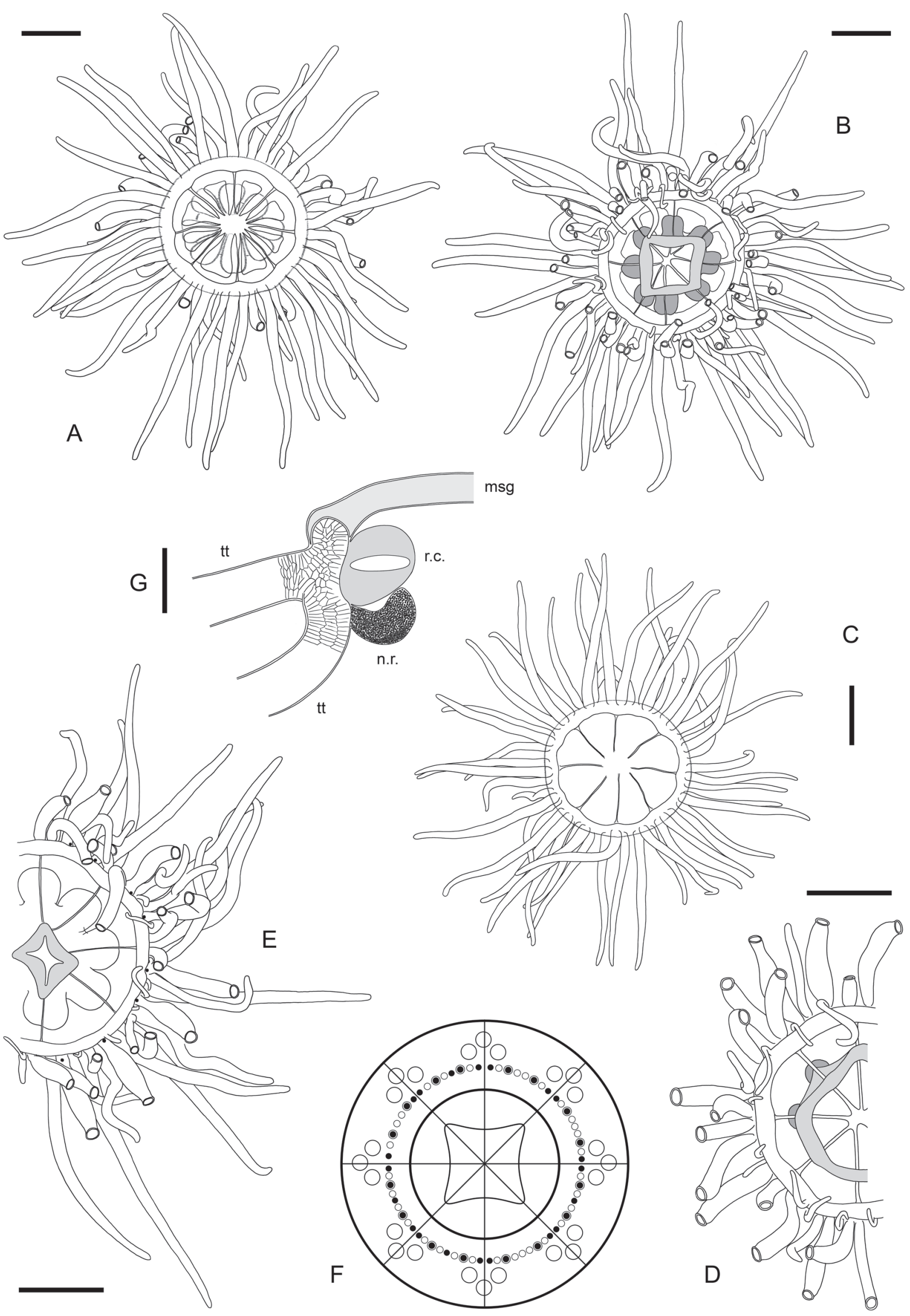




\section{Description}

Medusa up to $19 \mathrm{~mm}$ wide from tip to tip of opposite tentacles (Fig. 1C). Umbrella up to $6 \mathrm{~mm}$ in diameter, watch glass-shaped, evenly rounded, without marginal lobes (Fig. 1D-E). Mesoglea thin, thickening abruptly towards the margin, so as to accommodate a conspicuous belt of chordal cells, on which the tentacles are inserted; belt elongated-ovoid in cross section (Fig. 3G). Exumbrellar surface smooth, devoid of ribs and grooves; epidermis with scattered nematocysts. Manubrium eight-lobed in proximal half, quadrangular in distal half, projecting beyond aperture of subumbrella; gastric cavity with smooth (Fig. 1G) to slightly convoluted surface (Fig. 1F); mouth squared in contracted state (Figs 1G, 2E-F), and polygonal to almost rounded when distended (Fig. 1F); 4 simple lips (Fig. 2E-F), devoid of nematocysts, but containing numerous ciliated cells in epidermis. Eight broad, laterally flattened radial canals (Figs 1D-E, 2B), whose position coincides with that of the manubrial lobes, connect to an equally broad, circular canal, with thickened, granular walls (Fig. 2B), and an oral-aboral flattened lumen (Fig. 3G). Centripetal canals absent. Eight well-developed, triangularly-shaped mesenteries connect each manubrial lobe to the subumbrella along each radial canal (Fig. 2G-H). Tentacles solid, circular in cross section; two types: filiform and adhesive. Filiform tentacles (Fig. 1C, E-F) slightly constricted at origin (Fig. 2A), then swollen and tapering gradually towards their tips; provided with successive, closely-set rings of nematocysts in epidermis throughout their length (Fig. 2D); very contractile due to the presence of numerous, longitudinal myoepithelial cells; core composed of a mosaic of large, vacuolated cells (best seen in cross section), characteristically stacked along tentacle (particularly obvious in lateral view of tentacle). Adhesive tentacles stout and comparatively shorter than their filiform counterparts (Fig. $1 \mathrm{~F}-\mathrm{G}$ ), with similar internal structure, but epidermis with only very scattered nematocysts; distal ends with an adhesive pad (Fig. 2C). Sixteen groups of tentacles originate from the bell margin: 8 are perradial and 8 interradial (Fig. 1D); each group composed of (at least) three horizontal rows of superimposed tentacles; an aboral view of the exumbrella identifies each group through the presence of three large, adjacent, filiform tentacles, pointing both outwards and aborally, and representing the two proximal, aboral rows, their bases forming a triangle (Figs 1D, 2A, 3C); a third, more distal row, inserts close to lower side of umbrella margin, and is composed of a number of alternating adhesive and filiform tentacles, the latter being comparatively shorter than their counterparts from the two rows above (Figs 1F-G; 3D); two adjacent adhesive tentacles in each group are typically perradial (Figs $1 \mathrm{G} ; 3 \mathrm{D})$; number of additional tentacles in each group varied, and impossible to ascertain due to their crowded condition; however, 2-4 adhesive (exclusive of the perradial ones) and 2-4 filiform tentacles occur within each octant; the outermost adhesive tentacles (exclusive of the perradial ones) on both sides of each octant bear a free, ecto-endodermal statocyst at their bases (Fig. 3E-F); consequently, each medusa is provided with 16 of these sensory structures; statocysts small, short-stalked, with single, spherical statolith (Fig. 2I-K). A conspicuous and continuous cushion of nematocysts (Figs 1F-G, 2I), the insertion point of which is situated on the inner side of the distalmost row of tentacles, projects into the subumbrella and cups the lower side of the circular canal (Fig. 3G, n.r.). A velum is absent, with not even a vestige discernible. The gonads develop on each manubrial lobe; 8 broadly ovoid pairs are distinguished; members of each pair are separated by a mesentery (Figs $2 \mathrm{G}-\mathrm{H}, 3 \mathrm{~B}$ ); male gonads

Fig. 3 (previous page). Glaciambulata neumayeri Galea, Roder, Walcher, Warmuth, Kohlberg \& Fischer, gen. et sp. nov. A-B. Medusa in aboral (A) and oral (B) views. C. Aboral view of a medusa showing the arrangement of the upper row of large, filiform tentacles. D-E. Oral views of two medusae showing the arrangement of their adhesive tentacles (D) and the position of the statocysts (E). F. Composition and arrangement of marginal tentacles in a specimen (large, empty circles = large, filiform tentacles; small, empty circles $=$ small, filiform tentacles; small, black circles = adhesive tentacles; concentric circles, inner ones filled in $=$ adhesive tentacles with statocysts at their bases). G. Cross section through the umbrella margin ( $m s g$, mesoglea), showing insertion of tentacles ( $t t)$, the ring canal (r.c.), and the nematocyst ring (n.r.). Scale bars: $\mathrm{A}-\mathrm{E}=2 \mathrm{~mm} ; \mathrm{G}=500 \mu \mathrm{m}$. 
smooth-walled, comprising a translucent, moderately thick layer of sperm cells (Fig. 1G); female gonads with bumped surface (Fig. 2G), oocytes rather small and numerous, though their precise number could not be ascertained in fixed material. Cnidome (measurements given for undischarged capsules): 1) microbasic euryteles [7.69-8.04 $\mu \mathrm{m}$ long $(7.87 \pm 0.18 \mu \mathrm{m}, \mathrm{n}=17), 4.89-5.59 \mu \mathrm{m}$ wide $(5.17 \pm 0.18 \mu \mathrm{m}$, $\mathrm{n}=17$ )], in tentacles and also scattered in exumbrella (Fig. $\left.2 \mathrm{~L}^{6-8}\right) ; 2$ ) two size classes of stenoteles (in exumbrella, tentacles, outer wall of manubrium, gonads, and mesenteries), viz. small, ovoid capsules [8.04-10.13 $\mu \mathrm{m}$ long $(9.01 \pm 0.62 \mu \mathrm{m}, \mathrm{n}=19), 7.34-9.44 \mu \mathrm{m}$ wide $(7.98 \pm 0.61 \mu \mathrm{m}, \mathrm{n}=19)]$ (Fig. 2L $\left.\mathrm{L}^{4,5}\right)$ and large, nearly spherical capsules [12.28-15.73 $\mu \mathrm{m}$ long $(14.44 \pm 1.22 \mu \mathrm{m}, \mathrm{n}=16), 11.88-15.73 \mu \mathrm{m}$ wide $(14.28 \pm 1.40 \mu \mathrm{m}, \mathrm{n}=16)$ ] (Fig. $\left.2 \mathrm{~L}^{1-3}\right)$. Color: mesoglea and tentacles translucent; walls of radial and circular canals crowded with white pigment granules; gonads, manubrium, and nematocyst ring milky-white.

\section{Remarks}

There is generally one statocyst at the base of each of the outermost adhesive tentacle (exclusive of the perradial ones) in each octant. However, two exceptions to this rule have been observed: 1) a couple of statocysts occurred concomitantly in association with the insertion point of an adhesive tentacle; 2) a statocyst arose at the base of a filiform, instead of an adhesive, tentacle.

The tentacle arrangement illustrated in Fig. 3F exemplifies the case of a single specimen provided with a fair number of tentacles, and whose proper observations were possible due to its remarkable state of relaxation. However, the possibility cannot be excluded that, in medusae with a more significant number of tentacles, their arrangement may extend to more than three superimposed rows. Such specimens occur in the present collection, but the number and crowded condition of their tentacles prevented us from making accurate observations without injuring them.

The microbasic euryteles are tear drop-shaped and contain a short shaft with a thread forming four complete coils (Fig. 2L $\mathrm{L}^{6,7}$ ). No evaginated capsules were observed in fixed material, but their discharge was obtained upon a brief treatment with domestic bleach. In this case, a distally-swollen shaft, about as long as the capsule itself, bearing a few prominent spines apically, and with a long, distal thread covered with a succession of minute, closely-set, spirally-coiled spines, appeared (Fig. 2L ${ }^{8}$ ). These capsules proved identical to those described and illustrated by Hesthagen (1971) in Tesserogastria musculosa Beyer, 1959, and are, most probably, of the same type as those found in Ptychogastria polaris Allman, 1878 (Panteleeva et al. 1999).

Through the courtesy of Peter Schuchert of MHNG, the 16S and COI sequences of Glaciambulata neumayeri gen. et sp. nov. will be published on GenBank, once both the generic and specific names become available.

\section{Ecology}

Individuals were encountered attached upside down to the ice disks of the lowermost stratum of the subice platelet layer. Their distribution was patchy, ranging from areas devoid of animals to densities of up to 200 individuals $/ \mathrm{m}^{2}$. The uppermost, filiform tentacles were typically extended into the underlying water column, undulating under the impact of water motion, while their adhesive counterparts were firmly attached to the ice discs. The medusae could only be relocated from the ice by melting the substratum. Their mouths were stuck out towards the ice disks, and it is likely that the animals feed by grazing on algae and bacteria. The animals appeared to be incapable of swimming as they would sink immediately when detached from their ice disks. A perceptible movement, i.e. crawling, was not observed in situ, but was nevertheless evident in aquaria, where individuals held for other purposes changed positions within the tanks overnight. 
GALEA H.R. et al., Glaciambulata neumayeri gen. et sp. nov., a new Antarctic trachymedusa

\section{Distribution}

Known only from Atka Bay, eastern Weddell Sea (present study).

Genus Ptychogastria Allman, 1878

Pectyllis Haeckel, 1879: 265.

Pectanthis Haeckel, 1879: 267.

Pectyllis - Haeckel 1881a: 9; 1881b: 10.

Pectanthis-Haeckel 1881a: 17; 1881b: 19.

\section{Diagnosis}

Crawling ptychogastriid medusae with swimming capabilities; with dome-shaped, marginally-"lobed" umbrella, and eight-lobed manubrium, giving rise to as many mesenterial partitions of the subumbrellar cavity; mouth quadrangular, with simple lips; eight radial canals; centripetal canals either present or absent; eight pairs of gonads confined to the sides of the manubrial lobes; tentacles filiform and adhesive, occurring simultaneously and arranged in clusters around the bell margin; velum broad; 16 free, ectoendodermal statocysts ( 2 per octant).

\section{Remarks}

The diagnoses given by Bouillon \& Boero (2000) and Bouillon et al. (2006) are broadened again, so as to include the shape of the umbrella, the presence/absence of centripetal canals, and the presence of a velum, as Allman (1878) and/or Mayer (1910) did earlier.

As underlined by Mayer, the «differences between the genera "Pectyllis," "Pectis," and "Pectanthis," as defined by Haeckel, are so slight as to appear of specific rather than of generic value». Indeed, Haeckel (1879) distinguished Pectis (type species Pectis antarctica) from both Pectanthis (type species Pectanthis asteroides) and Pectyllis (type species Pectyllis arctica) through the presence of centripetal canals. In contrast, the tentacles were described as arranged in distinct groups in Pectanthis, and forming comparatively more contiguous groups in both Pectis and Pectyllis.

Similarly, Browne (1903) acknowledged earlier that "When Pectis antarctica and Pectanthis asteroides have been again examined it may be found that one genus with three species will be quite sufficient". However, it will be shown at the end of this paper that the former species does not belong to Ptychogastriidae, but to a different family of Trachymedusae, viz. Rhopalonematidae Russell, 1953.

\section{Key to species:}

1. Centripetal canals absent ....................................... asteroides (Haeckel, 1879)

- Centripetal canals present P. polaris Allman, 1878

\section{Ptychogastria asteroides (Haeckel, 1879)}

Fig. 4A-B

Pectanthis asteroides Haeckel, 1879: 267.

Pectanthis asteroides - Haeckel 1881a: 17, pls 7-8; 1881b: 20, pls 7, 8. - Browne 1903: 25, 26, 29. Maas 1906a: 492. — Bigelow 1909: 311. — Vanhöffen 1912: 386. — Beyer 1959: 126-130.

Ptychogastria asteroides - Mayer, 1910: 374. — Thiel 1932b: 478. — Kramp 1947: 5; 1957: 46; 1959: 180, 205, 223, 226; 1961: 241; 1968: 174. - Picard 1955: 68. - Bouillon 1985: 202. — Boero \& Bouillon 1993: 266. - Gili et al. 1998: 116, 126, 129, 131, 132; 1999: 232, figs 6-7; 2000: 1517, 1526. — Bouillon \& Boero 2000: 68. — Bouillon et al. 2000: 92; 2004: 240, fig. 152A-C; 2006: 112. 

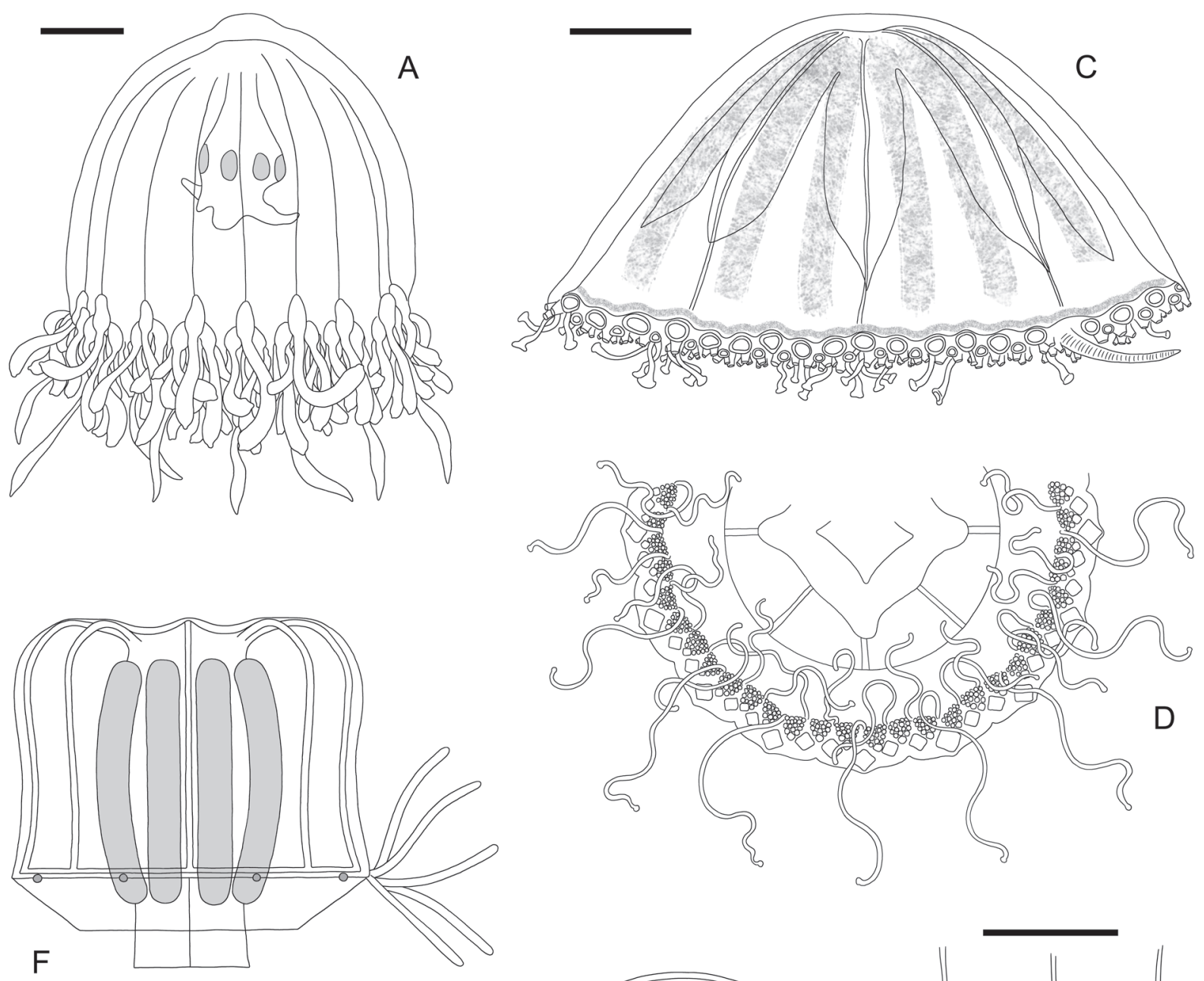

$\mathrm{F}$
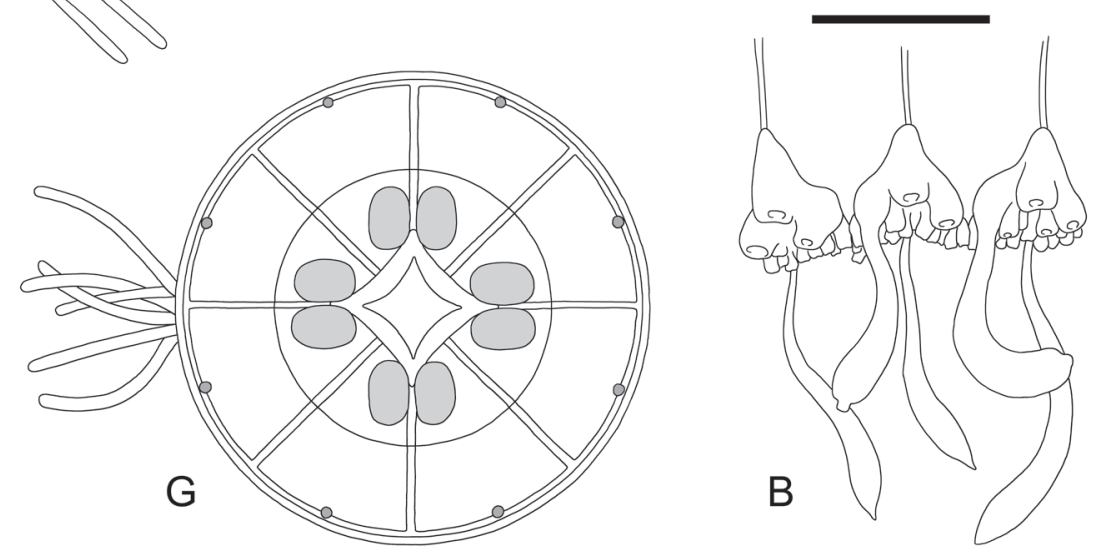

Fig. 4. - A-B. Ptychogastria asteroides (Haeckel, 1879). A. Lateral view of a medusa. B. Portion of umbrella margin showing the arrangement of tentacles. - C-E. Ptychogastria polaris Allman, 1878. C. Medusa in lateral view. D. Oral view of half of the medusa, showing the arrangement of the marginal tentacles. E. Portion of the bell margin, greatly enlarged. - F-G. Tesserogastria musculosa Beyer, 1959. Medusa in lateral (F) and oral (G) aspects. [A, B redrawn after Gili et al. (1999); C, E redrawn after Panteleeva et al. (1999); D redrawn after Haeckel (1881b); F, G redrawn after Hesthagen (1971)]. Scale bars: $\mathrm{A}, \mathrm{B}=500 \mu \mathrm{m} ; \mathrm{C}=3 \mathrm{~mm} ; \mathrm{E}=2 \mathrm{~mm}$. 


\section{Description}

Umbrella 1-2 mm high and 4-5 mm wide, dome-shaped in a contracted state, and comparatively flattened when relaxed. Mesoglea relatively thin, giving rise to a small, blunt, apical projection. Exumbrella with 16 radiating ribs ( 8 perradial and 8 interradial) alternating with as many grooves, giving the margin a "lobed" appearance. Each umbrellar "lobe" bears a group of 12-16 solid tentacles arranged in a few, horizontally stacked rows; the three large, uppermost tentacles filiform, borne on a conical projection enveloping their bases; projection crowded with irregular, refringent, likely mineral inclusions, as well as with stenoteles; additional tentacles of two types, filiform and adhesive; surface of all filiform tentacles covered with successive rings of spherical stenoteles of varied sizes; adhesive tentacles with a few, scattered stenoteles, ending distally in adhesive pads; a total of 200-260 tentacles per medusa. A free, pendant statocyst in middle of each umbrellar lobe, below the lowest row of tentacles; short, club-shaped, with single, spherical to elliptical statolith. Manubrium about half the length of the subumbrellar cavity; quadrangular proximally and eight-lobed towards middle; mouth with four simple lips crowded with mainly large stenoteles and granular, gland cells. Eight radial canals, bound to the wall of the manubrium through 8 shelf-like mesenteries, connect to the ring canal; centripetal canals absent. A continuous ring of nematocysts below the groups of tentacles. Velum thick and broad. Eight pairs of ovoid gonads on either side of the manubrial lobes; members of a pair separated through a mesentery. Cnidome: only stenoteles in two size classes reported to date. Color: perradial ribs of exumbrella purple-red, expanding distally into an ovoid spot of the same color; umbrella margin between the groups of tentacles yellowish; manubrium gold-yellow; tentacles translucent-yellow; adhesive disks red; gonads red.

\section{Remarks}

The tentacles of this medusa were described and illustrated by Haeckel (1881a, 1881b) as hollow, which made Kramp (1947) doubt about its affinities with the genus Ptychogastria. Later, Picard (1955) found the species again and stated that all its tentacles were solid. Haeckel also noted that "all sixteen [exumbrellar] ribs are tipped with nematocysts", but his statement was subsequently invalidated by Gili et al. (1999).

The shape of the manubrium, as well as the position of gonads in Haeckel's (1881b) account, is highly contradictory. In the legend of his fig. 1 (pl. 7), he stated: "In the middle [,] the golden-yellow base of the stomach with the surrounding corona of red genitalia shines through the umbrella" and, indeed, a pair of gonads is illustrated on either side of an eight-lobed manubrium. A similar condition is seen in his pl. 7 fig. 3. In contrast, his fig. 2, from the same plate, depicts a quadrangular manubrium and eight pairs of gonads originating from the proximal parts of the radial canals, thus apparently fitting the rather imprecise diagnosis he gave of the species (p. 20): "Eight egg-shaped genitalia in the proximal half of the radial canal (sic!), encircling the basis of the stomach in the form of an eight-rayed star, and halved by long radial mesogonia". However, Haeckel (1881b: 23) seems to clarify his observations by stating the following: "The eight genitalia [...] surround the basis of the stomach like an eight-rayed star". Although not making specific comments, a similar situation is seen in the more recent account by Gili et al. (1999: 324, fig. 6), who figured the gonads around a rather lobed manubrium, the unambiguous shape of which is even more evident in their fig. 7 (right drawing). It is worth noting that the manubrial lobes in this species are less developed than in P. polaris.

In addition, the position of the marginal "lobes" of the umbrella (and, consequently, of the groups of tentacles) seems to be erroneous in Haeckel's account. Indeed, he placed two lobes (with their respective tentacle groups) in each octant (pl. 7 figs 1-3), while Gili et al. (1999, fig. 7) illustrate 8 of them as perradial, and the remaining 8 as interradial. 


\section{Ecology}

Often recorded in both intermediate waters above submarine canyons and near the sea floor close to the continental shelf. Owing to the most frequent occurrence of the specimens in traps placed in intermediate waters than in those close to the bottom, lead Gili et al. (1999) to suspect that $P$. asteroides is a medusa that shows longer swimming periods compared to its congener $P$. polaris (see below). The specimens obtained by Picard (1955) from $10 \mathrm{~m}$ depth over a Posidonia bed are suspected to have been brought there fortuitously after a heavy sea episode. The normal bathymetric range varies between $200 \mathrm{~m}$ (Haeckel 1881b) and $1150 \mathrm{~m}$ (Gili et al. 1999).

\section{Distribution}

Many recent records are from the northern part of the Mediterranean basin (France and Spain) (Gili et al. 2000), but the species is known to extend its distribution westwards to the Strait of Gibraltar (Haeckel 1881b).

\section{Ptychogastria polaris Allman, 1878}

Fig. 4C-E

Ptychogastria polaris Allman, 1878: 290, figs 1-3.

Pectyllis arctica Haeckel, 1879: 266.

Ptychogastria opposita Vanhöffen, 1912: 386, fig. 20, pl. 25 fig. 6.

Ptychogastria polaris - Fewkes 1888: 43. - Browne 1903: 24, pl. 4, figs 1-2, pl. 5, figs 6-8. Maas 1906a: 482, 492, 493, 509. — Linko 1904: 218; 1913: 11. — Broch 1907: 4, 8; 1929: 491, fig. 6A-B. - Bigelow 1909: 301, 310; 1913: 41. — Mayer 1910: 372, fig. 212. — Vanhöffen 1912: 387. — Kramp 1914: 386-387, 395-396, 398, 427; 1942: 69, fig. 21; 1943: 6; 1947: 5, pl. 1, figs 1-4, pl. 6, figs 1-2; 1955: 158; 1957: 45, 98, 99; 1959: 180, 205, 209-211, 215, 221, 264, 268, 269, fig. 260; 1961: 241; 1968: 110, 148, 174, fig. 297. — Foerster 1923: 232, 264. — Kramp \& Damas 1925: 316. — Tanasijčuk 1927: 362. — Runnström 1932: 30. — Thiel 1932a: 151; 1932b: 444. — Bernstein 1934: 9, 25. — Yashnov 1940: 112; 1948: 73, pl. 21, fig. 1A-B. — Dunbar 1942: 74 - Vibe 1950: 103. - Rees 1953: 8. — Chiu 1954: 56. — Naumov 1956: 38; 1969: 610, fig. 457. — Beyer 1959: 124, 126, 129, 130. - Hesthagen 1971: 16. — Russell 1980: 3, fig. 6. — Bouillon 1985: 202. — Mackie 1985: 760, 761. — Stepanjants 1989: 416. — Antsulevich 1991: 41. — Larson et al. 1992: 277, 282, fig. 2C. - Sirenko et al. 1996: 348. — Stübing \& Piepenburg 1998: 193, fig. 1. — Gili et al . 1999: 325. - Panteleeva et al. 1999: 372, figs 1-10. — Bouillon \& Boero 2000: 68. — Miyake et al. 2004: 40, fig. 10. — Bouillon et al. 2006: 112. — Antsulevich 2015: 715, fig. 349.

Pectyllis arctica - Haeckel 1881a: 11, pls 3, 4; 1881b: 10, pls 3, 4. - Maas 1893: 20; 1906a: 482, 492. — Levinsen 1893: 146. — Aurivillius 1896: 194; 1899: 56. — Grönberg 1898: 465. — Browne 1903: 24, 25. — Bigelow 1909: 310. — Mayer 1910: 372. — Kramp 1914: 386-387; 1957: 46. — Beyer 1959: 128.

Ptychogastria opposita - Kramp 1947: 5; 1957: 45; 1961: 241. — Beyer 1959: 128.

\section{Description}

Umbrella dome-shaped to hemispherical, up to $12 \mathrm{~mm}$ high and $24 \mathrm{~mm}$ wide. Mesoglea moderately thick and transparent, conspicuously thickened towards margin of umbrella. Exumbrella with 16 radiating ribs ( 8 perradial and 8 interradial), alternating with as many grooves; an umbrellar "lobe" to each rib. Manubrium vasiform, about half as long as the height of subumbrella; proximal part divided into 8 lobes, visible as an 8-rayed "star" in an apical view of exumbrella; lower part quadrangular; mouth with four simple lips. Eight radial canals, narrow proximally when leaving the manubrium, then widening distally and becoming very broad and flat at junction with the ring canal; the latter equally broad, 
GALEA H.R. et al., Glaciambulata neumayeri gen. et sp. nov., a new Antarctic trachymedusa

giving rise to 8 interradial, centripetal canals, tapering gradually, and almost reaching the manubrium. Eight mesenteries connect each manubrial lobe to the subumbrella along a radius corresponding to each radial canal. All tentacles with solid cores, and showing a distinctive arrangement around the thickened bell margin: 48 isolated, filiform tentacles alternate with 48 clusters of additional, smaller tentacles. Filiform tentacles large, with triangular bases in cross section, 3 per umbrellar "lobe", 16 out of 48 being perradial (with respect to both radial and centripetal canals), while the remaining 32 are interradial. Each of the 48 clusters somewhat triangular in shape and projecting slightly outwards, comprising 16-20 comparatively shorter tentacles in 5-6 superimposed whorls; 3 upper tentacles (composing the two aboral-most rows) filiform (rounded in cross section, tapering gradually from base to tip), lower tentacles adhesive, with a few scattered nematocysts in epidermis, with narrow base, gradually widening distally, where they bear an adhesive pad. All filiform tentacles very contractile, epidermis containing numerous, successive rows of nematocysts, more densely crowded distally. Total number of tentacles reaching as many as 700-1000 per medusa. Sixteen small statocysts, 2 in each octant, arising from the inner side of umbrella margin, immediately below a group of adhesive tentacles; short-stalked, with single statolith. A conspicuous, uninterrupted ring of nematocysts along the margin of subumbrella. Velum very wide. Eight pairs of gonads, separated through mesenterial partitions, along the sides of the 8 manubrial lobes, not confined to the proximal parts of the radial canals, and not developing so as to reach the main body of the manubrium, becoming thus in contact with each other; gonads sac-shaped, elongated, with convoluted surface. Young medusae, $4-8 \mathrm{~mm}$ wide, already bear gonads and resemble the adults, thought the number of tentacle groups may be as low as 6. Cnidome: microbasic euryteles and stenoteles. Color: 32 red spots near margin of exumbrella, subumbrella light pink, gonads milky-white to orange, manubrium bright pink to deep red, mesenteries milky-white.

\section{Remarks}

According to Kramp (1955), when Haeckel (1879) described his Pectyllis arctica, "he was not aware that in the previous year it had been described by Allman as Ptychogastria polaris". Haeckel (1881b), after examining "an incomplete specimen" of Pt. polaris in the British Museum, reached the conclusion that it "appears closely related" to his Pe. arctica. Later, Browne (1903), upon reexamination of the type of Pt. polaris, found it in perfect agreement with Pe. arctica, and included the latter in the synonymy of Allman's species, an opinion followed later by all subsequent authors.

Though not providing a real description, Vanhöffen (1912) introduced the binomen Pt. opposita for southern specimens of a medusa "that do not markedly differ from the northern P. polaris", not excluding that "the two species will eventually prove identical", the main argument for keeping them distinct being the considerable remoteness of their respective areas of distribution. Kramp (1947), too, although acknowledging their great morphological similarities, kept them provisionally distinct for the same reason. He, however, was subsequently able to identify as $P$. polaris specimens from the South Shetland Islands, reaching the conclusion that $P$. opposita could be confidently sunk into synonymy of Allman's species (Kramp 1957).

Miyake et al. (2004) provided beautiful photographs of the medusa in situ, in both dorsal and ventral aspects. Panteleeva et al. (1999) gave comprehensive data on the cnidome composition of medusae from both the Pacific and Barents Sea.

The tentacle arrangement, as noted by Haeckel (1881b) "is very regular and peculiar. Each of the sixteen marginal lobes bears a principal group, composed of three larger sucking cups [=bases of broken filiform tentacles] and three triangular sucking-plates alternating with them, and in each sucking-plate we can distinguish sixteen to twenty sucking-cups [=mainly adhesive tentacles] of different sizes". Their arrangement is well illustrated by Haeckel in his Pl. 3, but his account is somehow misleading: there are, indeed, 3 large filiform tentacles within each umbrellar "lobe", but the number of groups of smaller 
tentacles alternating with them is only 2 , while additional groups are common to every two adjacent umbrellar "lobes". Panteleeva et al. (1999, fig. 5A-C) provided additional illustrations of the tentacular arrangement, supporting the accuracy of Haeckel's drawings.

It should be also noted that Allman's (1878) account ("Each tentacle corresponds to one of the notches which separate the marginal lobes") is equally erroneous with respect to the arrangement of tentacles. In fact, as stated above, 16 out of the 48 large, filiform tentacles are perradial, or the umbrellar notches are interradial; consequently, within each notch, there is a group composed of shorter, filiform and adhesive tentacles.

\section{Ecology}

This is an epibenthic species, spending the majority of its time attached to the sea floor (Panteleeva et al. 1999), occasionally being involved in short (ca 15 seconds) swimming episodes (Larson et al. 1992). It forages not only on sediment (Larson et al. 1992; Stübing \& Piepenburg 1998; Panteleeva et al. 1999), but also on hard substrates (Miyake et al. 2004). According to Panteleeva et al. (1999), P. polaris is definitely a cold-water species. Its bathymetric range of occurrence is between $10 \mathrm{~m}$ (Kramp 1947) and $2500 \mathrm{~m}$ (Stepanjants 1989).

\section{Distribution}

A mainly boreal-arctic species (Panteleeva et al. 1999), sporadically recorded from other locations around the world, such as Monterey Bay, California (Larson et al. 1992), Japan (Miyake et al. 2004), and Antarctic to subantarctic waters (Kramp 1957 and Vanhöffen 1912, respectively).

Genus Tesserogastria Beyer, 1959

\section{Diagnosis}

Crawling medusae with swimming capabilities; umbrella bell-shaped, margin thickened, provided with a great number of solid, filiform tentacles inserted at varied levels, apparently not forming distinct rows or clusters; manubrium cross-shaped, with four perradial lobes; gastric peduncle, pouches and mesenteries absent; 8 radial canals join the broad ring canal; centripetal canals absent; four pairs of elongated gonads, one to each manubrial lobe; velum well-developed; 8 free, ecto-endodermal statocysts ( 2 per octant).

\section{Remarks}

The absence of both mesenteries and adhesive tentacles, as well as the shape and position of the gonads, immediately distinguish this genus from both Glaciambulata gen. nov. and Ptychogastria Allman, 1878.

Tesserogastria musculosa Beyer, 1959

Fig. 4F-G

Tesserogastria musculosa Beyer, 1959: 122, pls 1-2.

Tesserogastria musculosa - Hesthagen 1971: 3, figs 2-10. — Bouillon 1985: 202. — Larson et al. 1992: 284. - Bouillon et al. 2006: 112.

\section{Description}

Umbrella bell-shaped, about as high as broad (up to $2.5 \mathrm{~mm}$ ), with a small, blunt, apical projection surrounded by a circular depression. Exumbrella devoid of radial ridges. Mesoglea rather thin, comparatively thickened at margin, accommodating a belt of chordal cells on which the tentacles insert. Over 300 tentacles, inserted at 3-5 superimposed levels, apparently not forming distinct rows or clusters; solid, core composed of a single row of chordal cells; proximally constricted, leaving tear drop-shaped 
GALEA H.R. et al., Glaciambulata neumayeri gen. et sp. nov., a new Antarctic trachymedusa

scars when shed; blunt-ended to pointed distally, and there devoid of adhesive pads; nematocysts evenly dispersed in epidermis, except for the distal tip, where they are comparatively crowded. Manubrium cross-shaped (four perradial lobes are distinguishable), except proximally where it assumes an octagonal shape at the origin of the radial canals; relatively long, though devoid of a peduncle, and extending somewhat beyond the bell margin; mesenteries absent; mouth square, with four simple lips provided with ciliated cells in the epidermis. Eight radial canals with rounded cross sections connect to the broad ring canal, elliptical in cross section, longer axis oral-aboral; centripetal canals absent. A conspicuous nematocyst ring on lower side of umbrella margin. Velum extremely broad and strong. Eight slender, elongated gonads, in four perradial pairs; one pair confined to each manubrial lobe. Eight small, shortstalked, interradial statocysts with single, spherical statoliths; one statocyst in each octant. Cnidome: almost spherical stenoteles $[(7-8) \times(6-7) \mu \mathrm{m}]$, tear drop-shaped microbasic euryteles [(4-7) $\times(3-$ 5) $\mu \mathrm{m}$ ], and atrichous isorhizas (ca $2 \mu \mathrm{m}$ ); the capsules occur in both tentacles and the marginal ring. Color: umbrella translucent, with white to yellow epidermal spots at junction of radial canals with the ring canal.

\section{Remarks}

Although the tentacles were described as "not arranged in distinct rows, nor in clusters" around the bell margin, Beyer (1959) acknowledged that "It is possible, however, to trace some repetition in the arrangement, and this makes 48 groups [...]. The pattern is thus not quite unlike that of Ptychogastria polaris Allman [...]". However, no further details were given relative to the position of these groups with respect to the radial canals. Their presence, if confirmed again, would not be surprising, given that more or less distinct groups of tentacles can be found in both Ptychogastria and Glaciambulata, the sole marked difference in this respect being the total absence of tentacles with adhesive pads in Tesserogastria. Though no such structures have been observed, "The amount of debris so frequently found to be sticking to the tentacle ends indicate that they are adhesive" (Beyer 1959). The so called adhesion is, most probably, due to the crowded condition of the nematocysts in the tentacle tips (Beyer 1959), and the possible glutinant nature of some of them (Hesthagen 1971).

The development from the egg, and the behavior of the medusa were thoroughly documented by Hesthagen (1971).

\section{Ecology}

A soft bottom species, never captured in plankton nets or vertical hauls (Beyer 1959). The medusae move extremely slowly, and have never been observed to swim in captivity, unless they were forced to do so and, in this case, their swimming was jerky. Specimens of this species have been collected between 60-350 m (Hesthagen 1971).

\section{Distribution}

Only known from the Norwegian coast of the North Sea, between Bergen and Oslo (Hesthagen 1971).

Family Rhopalonematidae Russell, 1953

Genus Pectis Haeckel, 1879

Pectis Haeckel, 1879: 266; 1881a: 12; 1881b: 14.

Voragonema Naumov, 1971: 13 (syn. nov.).

Voragonema - Bouillon \& Boero 2000: 69, 73. - Bouillon et al. 2006: 113, 121. - Antsulevich 2015: 717-718, 727, 773. 


\section{Diagnosis}

Rhopalonematid medusae with dome-shaped umbrella; exumbrella with numerous, fine, meridional ridges; subumbrella pigmented; with gastric peduncle; manubrium with or without outer gastric pouches; mouth with 4 simple lips; 8 radial canals connect to the ring canal, the latter giving rise to a varied number of regularly- or irregularly-shaped centripetal canals; 8 narrow, elongated gonads, distally pendant, on the radial canals; tentacles very numerous, in superimposed rows, of two types: outermost large and solid, and innermost thinner, shorter and hollow; statocysts numerous and free.

\section{Remarks}

When Haeckel (1879) described the genus Pectis, he notably emphasized the "eight genitalia in the course of the eight radial canals, between which blind centripetal canals run from the annular canal". It will be shown in the next section that its type species, $P$. antarctica Haeckel, 1879, shows all the distinctive characters of the genus Voragonema Naumov, 1971, and in particular of $V$. laciniata Bouillon et al., 2001.

Reversal of precedence (ICZN Art. 23.9) for the generic name cannot be applied for the following reasons: the senior synonym, Pectis, has been used as a valid name after 1899 (e.g., Browne 1903: 29), so Art. 23.9.1.1. is not fulfilled; the junior synonym, Voragonema, has been used, to our knowledge, in only 22 out of the 25 published works etc., required to meet the conditions of Art. 23.9.1.2. The presumed valid name appears in: Naumov (1971), Bouillon (1985), Beliaev (1989), Larson \& Harbison (1990), Larson et al. (1991), Bouillon (1993), Gili et al. (1998), Bouillon \& Boero (2000), Bouillon et al. (2001), Thuesen (2003), Bouillon et al. (2006), Stepanjants et al. (2006), Stepanjants (2007), Pagès et al. (2007), Hosia et al. (2008), Lindsay \& Miyake (2009), Lindsay \& Pagès (2010), Zeidler (2012), Antsulevich (2015), Chen et al. (2015), Jamieson (2015), and Minemizu et al. (2015).

Consequently, the genus Pectis is taken as valid, and Voragonema is included in its synonymy. Presently, the genus contains four species, namely: P. antarctica, P. pedunculata (Bigelow, 1913), P. profundicola (Naumov, 1971), and P. tatsunoko (Lindsay \& Pagès, 2010).

The diagnosis given above is based on that provided by Bouillon et al. (2006) for the genus Voragonema Naumov, 1971, and it is broadened so as to include the bell shape, the presence of meridional ridges on the exumbrella, the colored subumbrella, the shape of the gonads, and the types of marginal tentacles.

The gastric pouches are recognized as specific rather than generic features. Indeed, they are present in $P$. antarctica, but are lacking in both $P$. pedunculata and $P$. tatsunoko. It is unclear whether the eight wavy manubrial ridges reported by Naumov (1971) in P. profundicola represent the same anatomical structures.

Several authors (Bouillon et al. 2001; Lindsay \& Pagès 2010) drew attention to several supposed "peculiarities" exhibited by the type species of the genus Voragonema, V. profundicola, notably:

1) the apparent lack of pigmentation of its subumbrella. Indeed, besides the transparent umbrella, the brown manubrium, and the colorless radial canals and tentacles, Naumov (1971) did not make any specific reference to the pigmentation of the subumbrella, though he stated that the colors exhibited by his species were typical of deep-water medusae. It is likely, however, that the color of the subumbrella in these species fades over time, as remarked on by Bigelow (1913) in P. pedunculata: "the pigmentation covered the entire subumbrella, though now it is intact over occasional patches only". On the other hand, some species, such as $P$. tatsunoko, may be only lightly pigmented in life ("subumbrella pale roseorange", Lindsay \& Pagès 2010), and the color of fixed specimens changes to nearly white-opaque (see Fig. 2A in their paper). 
GALEA H.R. et al., Glaciambulata neumayeri gen. et sp. nov., a new Antarctic trachymedusa

2 ) the lesser number of marginal tentacles (ca 500, Naumov 1971), compared to that of $P$. antarctica (1000-1200), P. pedunculata (1000-2000), and P. tatsunoko (ca 1050) (Lindsay \& Pagès 2010). However, it should be noted that the type of $P$. profundicola was a young, immature specimen, measuring only 1 $\mathrm{cm}$ high and $1.5 \mathrm{~cm}$ wide (Naumov 1971), while much larger individuals were obtained for $P$. antarctica (30 $\mathrm{mm}$ high and $35 \mathrm{~mm}$ wide), P. pedunculata (up to $31 \mathrm{~mm}$ high and $41 \mathrm{~mm}$ wide), and P. tatsunoko (14 mm high and $19 \mathrm{~mm}$ wide) (Lindsay \& Pagès 2010). Since it is acknowledged that tentacles are added continually to the bell margin during the growth of the medusa, it is not surprising for there to be a lesser number in younger individuals compared to more aged ones.

3 ) the lack of gonads in the type. It is highly improbable that the gonads of this rhopalonematid medusa are formed elsewhere than along the radial canals.

The genus Pectis is immediately distinguished from its allies Benthocodon Larson \& Harbison, 1990, Crossota Vanhöffen, 1902, and Vampyrocrossota Thuesen, 1993 through the presence of centripetal canals arising from the ring canal. It shares the presence of exumbrellar furrows with both Crossota and Vampyrocrossota, the occurrence of a gastric peduncle with Benthocodon, and the presence of statocysts, again, with Crossota.

Pectis antarctica Haeckel, 1879

Fig. 5, Table 2

Pectis antarctica Haeckel, 1879: 266.

Voragonema laciniata Bouillon et al., 2001: 841, figs 4-5 (syn. nov.).

Pectis antarctica - Haeckel 1881a: 13, pls 5-6; 1881b: 15, pls 5-6. - Browne 1903: 29. - Maas 1906a: 484. — Kramp 1957: 46. — Beyer 1959: 128.

Ptychogastria antarctica - Maas 1906a: 493; 1906b: 19. - Mayer 1910: 375. - Vanhöffen 1912: 386. — Thiel 1932b: 478. — Kramp 1947: 5; 1957: 46; 1961: 241; 1968: 111, 174. — Bouillon \& Boero 2000: 68. - Bouillon et al. 2006: 112.

Voragonema laciniata - Lindsay \& Pagès 2010: 36-37.

\section{Remarks}

According to Haeckel (1879, 1881a, 1881b), Pectis antarctica is a hydromedusa exhibiting the following characters: 1) bell nearly hemispherical; 2) exumbrella finely ribbed radially; 3) mesoglea moderately thick in the upper half, and comparatively thinner in the lower half; 4) eight radial canals connecting with the ring canal, the latter giving rise to 11-13 centripetal canals in each octant; 5) eight ovoid, convoluted gonads, extending along the proximal half of the radial canals; 6 ) a quadrangular manubrium provided with 8 pairs of outer, hollow, hemispherical pouches; 7) a strong, muscular velum; 8) a great number of solid marginal tentacles not arising in distinct clusters, but showing a certain regularity in their arrangement around the bell margin; 9) a continuous ring of nematocysts between the velum and the lowest row of tentacles; 10) the occurrence of a number of free, small, club-shaped statocysts with single, spherical statoliths.

In light of these characters, especially the presence of centripetal canals, also found in Ptychogastria polaris Allman, 1878, Maas (1906a) transferred Haeckel's species to the genus Ptychogastria Allman, 1878. He acknowledged only "relative" differences in the arrangement of the marginal tentacles, and noted a remarkable reduction of the "mesenteries" (sic!) compared to both Pt. polaris and Pt. asteroides (Haeckel, 1879). 

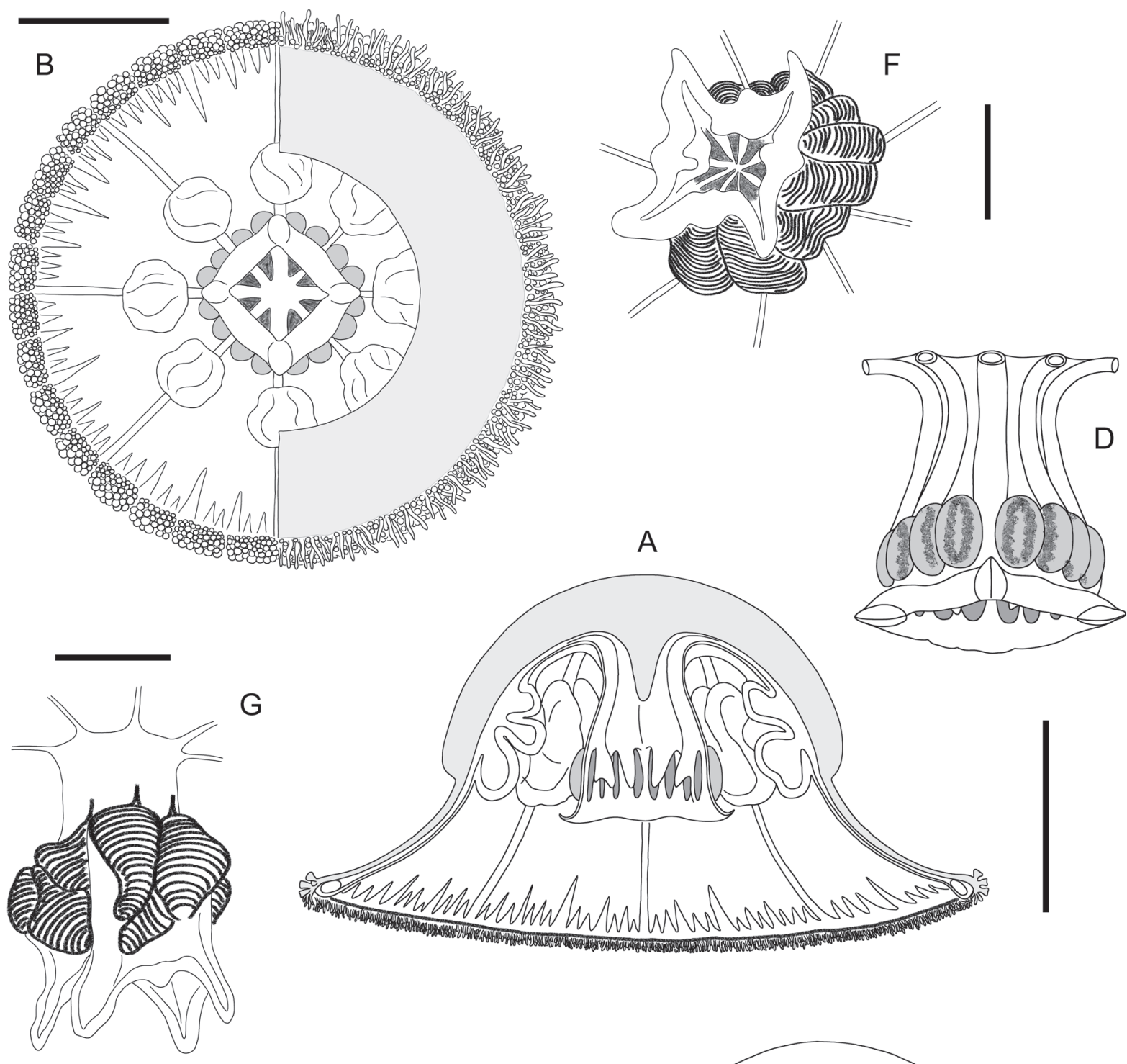

A
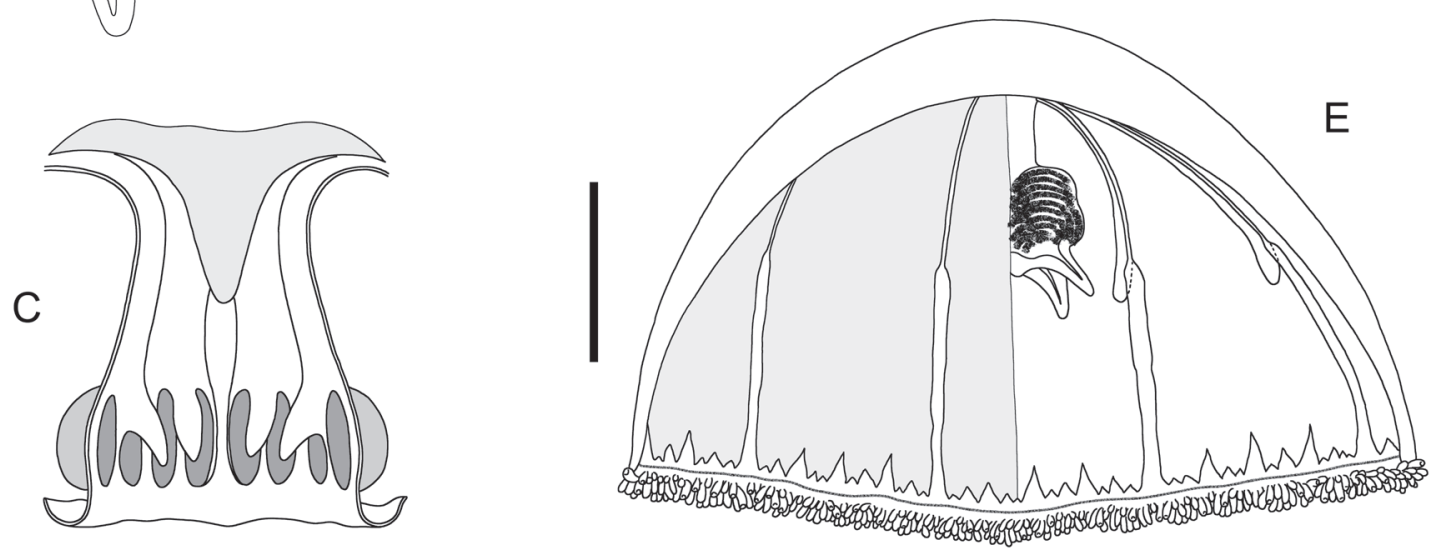

Fig. 5. - Pectis antarctica Haeckel, 1879. A-B. Medusa in lateral (A) and oral (B) views. C. Longitudinal section through the manubrium. D. Lateral view of the manubrium showing the outer, gastric pouches. E. Lateral view of Voragonema laciniata Bouillon et al., 2001. F-G. Manubrium of V. laciniata in oral (F) and lateral (G) views. [A-D redrawn after Haeckel (1881b); E-G redrawn after Bouillon et al. (2001)]. Scale bars: A, B, E = $1 \mathrm{~cm} ; \mathrm{F}, \mathrm{G}=5 \mathrm{~mm}$. 
GALEA H.R. et al., Glaciambulata neumayeri gen. et sp. nov., a new Antarctic trachymedusa

Table 2 (continued on next page). Morphological comparison between the nominal species Pectis antarctica Haeckel, 1879 and Voragonema laciniata Bouillon et al., 2001.

\begin{tabular}{|c|c|c|}
\hline & P. antarctica Haeckel, 1879 & V. laciniata Bouillon et al., 2001 \\
\hline References & Haeckel (1881b) & Bouillon et al. (2001), Lindsay \& Pagès (2010) \\
\hline Distribution & $\begin{array}{l}60^{\circ} 52^{\prime} \mathrm{S}, 80^{\circ} 20^{\prime} \mathrm{E}(500-600 \mathrm{~km} \text { off eastern } \\
\text { Antarctica) }\end{array}$ & Weddell Sea, Antarctica \\
\hline \multirow[t]{5}{*}{ Umbrella } & 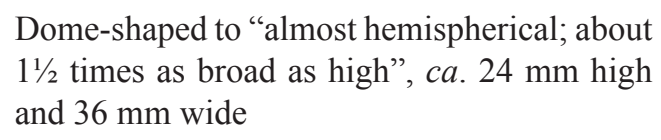 & $\begin{array}{l}\text { Dome-shaped to hemispherical, almost as high } \\
(30 \mathrm{~mm}) \text { as wide }(35 \mathrm{~mm})\end{array}$ \\
\hline & "Exumbrella finely radially ribbed" & $\begin{array}{l}\text { Exumbrella transparent, with numerous fine, } \\
\text { meridional ridges }\end{array}$ \\
\hline & $\begin{array}{l}\text { "The gelatinous substance of the umbrella } \\
{[\ldots] \text { is nearly of equal thickness in the upper }} \\
\text { aboral half of the umbrella"; "much thinner in } \\
\text { the lower oral half, hardly one-fourth or one- } \\
\text { fifth as thick as in the upper half" }\end{array}$ & $\begin{array}{l}\text { Mesoglea } 4 \mathrm{~mm} \text { thick in the apex, thinning out } \\
\text { towards umbrella margin }\end{array}$ \\
\hline & $\begin{array}{l}\text { "The ectodermal epithelium of }[\ldots] \text { the } \\
\text { subumbrella consists of cells of dark brown } \\
\text { pigment" }\end{array}$ & Subumbrella dark red-brownish colored \\
\hline & $\begin{array}{l}\text { "The underlying annular system of the } \\
\text { subumbrella forms numerous compact } \\
\text { circular folds" }\end{array}$ & $\begin{array}{l}\text { Musculature of subumbrella consisting of both } \\
\text { circular and crossed oblique-radial muscles }\end{array}$ \\
\hline $\begin{array}{l}\text { Gastric } \\
\text { peduncle }\end{array}$ & $\begin{array}{l}\text { The mesoglea "is very much thickened in the } \\
\text { centre of the apex, and projects into the fundus } \\
\text { of the gastral cavity in the form of a short, } \\
\text { conical, gelatinous appendage" }\end{array}$ & $\begin{array}{l}\text { Large, circular from above and slightly octagonal } \\
\text { from the subumbrellar cavity }\end{array}$ \\
\hline Canal system & $\begin{array}{l}\text { "The eight radial canals }[\ldots] \text { which run from } \\
\text { the basis of the stomach to the umbrella } \\
\text { margin, and there open into the circular canal, } \\
\text { as well as the circular canal itself }[\ldots] \text {, and the } \\
\text { blind centripetal canals proceeding from it, } \\
\text { are not cylindrical tubes, but flattened band- } \\
\text { like vessels which are sharply distinguished } \\
\text { by then milk-white colour from the dark } \\
\text { violet subumbrella"; "11-13 blind radial } \\
\text { canals ( } 3 \text { larger and } 8-10 \text { smaller) between } \\
\text { each two radial canals }[\ldots] \text { have the form of } \\
\text { a pointed equilateral triangle"; "number and } \\
\text { arrangement }[\ldots . . .] \text { not perfectly regular" }\end{array}$ & $\begin{array}{l}8 \text {, white-cream colored, straight; peduncular } \\
\text { part } 5 \mathrm{~mm} \text { long and } 1.5 \mathrm{~mm} \text { wide; proximal half } \\
\text { of the subumbrellar part narrow, } 0.5 \mathrm{~mm} \text { wide, } \\
\text { distal half broader, } 1.3 \mathrm{~mm} \text { wide. Ring canal } \\
\text { wide, giving rise to } 11-13 \text { conically-shaped, } \\
\text { irregular in length and width, centripetal canals } \\
\text { in each octant }\end{array}$ \\
\hline \multirow[t]{2}{*}{ Manubrium } & $\begin{array}{l}\text { "The central oesophagus hangs down from } \\
\text { the fundus of the umbrella cavity till past the } \\
\text { middle of it in the shape of a quadrangular } \\
\text { tube [...]" }\end{array}$ & $\begin{array}{l}\text { Short, broad, square, slightly longer than the } \\
\text { peduncle, with thick muscular walls. Gastric } \\
\text { peduncle and manubrium taken together about } \\
\text { half the height of the sumbumbrella cavity. }\end{array}$ \\
\hline & $\begin{array}{l}\text { "Oral cavity with with } 8 \text { pairs of hemispherical } \\
\text { side pouches". "These form hemispherical, or, } \\
\text { more properly, semioval evaginations of the } \\
\text { gastral wall, and hang together in pairs in such } \\
\text { a way that eight pairs appear as oral bifurcated } \\
\text { terminal shoots of the eight gastral grooves" }\end{array}$ & $\begin{array}{l}\text { Manubrial cavity divided into eight } \\
\text { longitudinally folded gastric pouches that open } \\
\text { into the radial canals. The presence of septal } \\
\text { pouches presumably increases the absorption } \\
\text { surface of the endoderm. }\end{array}$ \\
\hline
\end{tabular}




\section{P. antarctica Haeckel, 1879}

\section{V. laciniata Bouillon et al., 2001}

"Oral margin fleshy and thickened, quadrate, Mouth with four prominent, elongated perradial with four radial oral tentacles" (sic!). "These lips, and swollen interradial edges folds are divided into four interradial groups by four perradial longitudinal muscles, ending in the four short heart-shaped oral lobes"

Gonads "The eight genitalia [...] are wide, folded, 8, extending along the proximal half of the thick-walled pouches, which occupy the radial canals; flattened, with distal part free and proximal half of the radial canals" slightly pendant

Nematocyst "Umbrella margin, thickened into a roll"
ring

Velum

Tentacles

Statocysts "about a thousand". illustrated in Haeckel's Pl. 3 Fig. 12.
"The velum $[\ldots]$ is distinguished by a Wide, with marked circular muscles very unusual development of the muscular system", and is characterized by the presence of "numerous highly-developed circular folds". "The breadth of the velum is so great that when fully extended it can probably close the entire umbrella cavity like a sphincter"

"The numerous sucking-cups (sic!) form 6 About 1200 per medusa, ca 150 per octant, to 8 alternating rows placed one above the superimposed in 5-6 rows; their size increases other on the umbrella margin; in each of the from the adaxial to the abaxial side thirty-two small groups, which have an almost rhomboidal outline, they are placed in 5 to 6 diagonal rows, each with 4 to 5 tentacles";

Types, shapes and arrangement well- 2 types of tentacles: solid, with adnate base in the outermost row, and shorter and thinner in the innermost rows "The auditory clubs (sic!) [...] lie on the Numerous, free, placed among the marginal
axial side of the umbrella margin, under the tentacles; with single, large statoliths insertion of the velum, inside the lowest row of tentacles. After most careful search, I was only able to discover two or three of them, very small"

According to Browne (1903), the type specimen of Pe. antarctica "had been thoroughly dissected by Haeckel and just a few pieces placed back into a bottle", an observation later confirmed by Kramp (1957), who added that the "tiny fragments [...] give no idea of the original appearance of the medusa".

Earlier, Kramp (1947) acknowledged that "Ptychogastria antarctica (Haeckel) differs too much from P. polaris to be placed in the same genus, or even in the same family". Later, he added: "if Haeckel's account $[\ldots]$ is correct, this species is entirely different from P. polaris (including opposita)" (Kramp 1957). He noted that "the numerous and closely packed tentacles were not arranged in groups as in $P$. polaris. The ring of tentacles seems to be homogenous, equally thick and dense".

Although his remark is entirely justified, a couple of morphological features resulting from Haeckel's (1881b) account are noteworthy: 
GALEA H.R. et al., Glaciambulata neumayeri gen. et sp. nov., a new Antarctic trachymedusa

1) unlike Ptychogastria, the gonads of which occur in pairs on either side of the manubrial lobes, those of Pe. antarctica are not only confined to the radial canals, but they also exhibit a radically different shape, being "wide, folded, thick-walled" and slightly pendant distally (Haeckel 1881b: pl. 5 fig. 2);

2) the mesoglea of Pe. antarctica is "very much thickened in the centre of the apex, and projects into the fundus of the gastral cavity in the form of a short, conical, gelatinous appendage", leaving no doubts that this corresponds in fact to a gastric peduncle, even though the illustrations given by Haeckel (1881b: pl. 5 figs 2, 4) are misleading.

It is realized that, taken together, the morphological characters displayed by Pe. antarctica are distinctive features of the genus Voragonema Naumov, 1971. Among the four species assigned to it (see Lindsay \& Pagès 2010), V. laciniata Bouillon et al., 2001, originating from the Weddell Sea, shows striking resemblances with the present species, and both are thought to be coterminous.

Table 2 compares all morphological characters assigned by Haeckel (1881b) to his Pe. antarctica with those provided by Bouillon et al. (2001) for their V. laciniata. It is, however, acknowledged that several morphological features described by Haeckel are a matter of debate. For example, the shape of the umbrella is rather peculiar, and it may represent an artifact resulting from a strong contraction during the hauling and/or fixation of the type material, as already suggested by Vanhöffen (1912). Indeed, a similar shape is assumed post-collection and fixation by the medusae of $P$. tatsunoko (Lindsay \& Pagès 2010, Fig. 2A-B). In addition, a strong contraction of the umbrella would explain the presence of the "thirtytwo more prominent ribs towards the margin" reported by Haeckel.

The "eight narrow mesogonia" apparently occurring in Pe. antarctica represent, with little doubt, nothing more than the proximal parts of the gonads. The observation that the tentacles are "rather arranged in eight larger and thirty-two smaller groups" (Haeckel 1881b) around the umbrella margin, is possibly not totally unfounded. Indeed, Lindsay \& Pagès (2010) noted a "regular pattern" in the arrangement of tentacles in P. tatsunoko, and it is quite possible that a similar situation may occur in Haeckel' species as well.

Last but not least, Haeckel's statement that "All the tentacles of this genus are solid; their endodermal axis consists of large, clear chordal cells which are sometimes placed in a discoid row one behind the other" is more problematic in its interpretation. Indeed, we cannot be sure whether or not Haeckel made sections through both the large, outermost and the shorter, innermost tentacles, given that only the latter are reportedly hollow in Pectis (Lindsay \& Pagès 2010, as Voragonema). It has been proved, indeed, that Haeckel's observations on the hollow nature of the tentacles of Pt. asteroides were totally unfounded (Picard 1955), even though he provided an illustration (Haeckel 1881b: pl. 7 fig. 4), of apparently irrefutable evidence, to support his statement. It is also interesting to note that Bouillon et al. (2001) noted only hollow tentacles in P. laciniata, although it was shown that two types, solid and hollow, occur in this species (Lindsay \& Pagès 2010).

Reversal of precedence for the specific name could not be applied for the following reasons: the senior synonym, antarctica, has been used several times as a valid name after 1899 (see synonymy), so the conditions relative to Art. 23.9.1.1. are not met; the junior synonym, laciniata, has been used only five times in the literature (Bouillon et al. 2001, 2006; Stepanjants et al. 2006; Lindsay \& Pagès 2010; Mahuzier \& Sylvestre 2016), instead of at least 25 times, and Art. 23.9.1.2. is not fulfilled.

Consequently, prevailing usage of laciniata could not be maintained, and this name should be assigned to synonymy with antarctica. For a modern description of this species, refer to Bouillon et al. (2001, as V. laciniata). 


\section{Ecology}

Almost nothing, except for the depth range of its habitat, is known about the ecology of this species. It was recorded from $1583 \mathrm{~m}$ (Bouillon et al. 2001) and ca $2300 \mathrm{~m}$ (Haeckel 1881b).

\section{Distribution}

Recorded so far from two localities, one situated 500-600 km off eastern Antarctica (6052' S, 80 $20^{\circ}$ ' E;

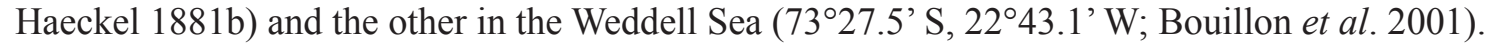

\section{Discussion}

Anew hydromedusa is described based on specimens from western Antarctica. Some of its morphological features, viz. the number of radial canals, the number and arrangement of gonads, the lack of a gastric peduncle, the numerous tentacles occurring in superimposed rows, and the presence of free statocysts, place it within the family Ptychogastriidae Mayer, 1910. Unlike both Ptychogastria Allman, 1878 and Tesserogastria Beyer, 1959, this medusa has a flattened, watch glass-shaped umbrella, and is devoid of a velum. These features justify the creation of a new, presently monotypic genus, Glaciambulata, to accommodate these new character combinations.

The revision of the genus Ptychogastria provided herein demonstrates that Pectis antarctica Haeckel, 1879 , a species assigned to it by a number of authors, does not belong here. Indeed, its finely ribbed exumbrella, the pigmented subumbrella, the presence of a gastric peduncle and of centripetal canals, the number and arrangement of gonads, the types and arrangement of the marginal tentacles, and the occurrence of free statocysts, are characters of the contemporary rhopalonematid genus Voragonema Naumov, 1971. Moreover, it is demonstrated that $V$. laciniata Bouillon et al., 2001 is coterminous with $P$. antarctica, thus clarifying the morphology and the taxonomic status of this poorly-known species, 137 years after its discovery. The binomen Pectis antarctica is retained in light of the Principle of Priority of ICZN.

\section{Acknowledgements}

C.R., C.W., M.W., E.K. and P.F.F. would like to thank the logistics department of the Alfred-WegenerInstitut, Helmholtz Center for Polar and Marine Research, for managing the unique transportation of freight and samples to and from Antarctica, and the Neumayer overwintering crew 2015/2016, as well as the peak season staff at Neumayer III during our expedition for indispensable support in fieldwork. Peter Schuchert (MHNG) is warmly thanked for useful comments on an earlier version of this report, for suggesting the generic name of the new medusa, and for obtaining its DNA sequences. Dale R. Calder (Royal Ontario Museum, Canada) gave his best advice on ICZN matters, and Alexander E. Antsulevich (Saint Petersburg State University, Russia) kindly translated from Russian the description of Voragonema profundicola. Gratitude is extended to Aino L.J. Hosia (University Museum of Bergen, Norway) and Dhugal J. Lindsay (Japan Agency for Marine-Earth Science \& Technology) for their thorough reading of the manuscript and their helpful suggestions.

\section{References}

Allman G.J. 1878. Appendix No. XI. Hydrozoa. In: Feilden H.W. (ed.) Narrative of a voyage to the Polar Sea during 1875-6 in H.M. ships "Alert" and "Discovery" by Capt. G.S. Nares 2: 290-292. Sampson Low, Marston, Searle \& Rivington, London. http://dx.doi.org/10.5962/bhl.title.6828

Antsulevich A.E. 1991. Ob endemizme Belomorskoĭ fauny gidroidov i svyazi mezhdu faunami Belogo i Barentseva moreĭ. On the White Sea hydrozoan fauna endemismus: White and Barentz Seas faunas connection. In: Bentos Belogo Morya. Populyatsii, biotsenozy, fauna. Trudy Zoologicheskogo Instituta, Akademiya Nauk SSSR 233: 35-43. Akademiya Nauk, Moscow. 
GALEA H.R. et al., Glaciambulata neumayeri gen. et sp. nov., a new Antarctic trachymedusa

Antsulevich A.E. 2015. Hydrozoa (Hydroids and Hydromedusae) of Russian seas. St. Petersburg University Press, St. Petersburg.

Aurivillius C.W.S. 1896. Das Plankton der Baffins Bay und Davis' Strait. In: Almqvist \& Wiksellz Boktryckeri-Aktiebolag (eds) Zoologiska Studier. Festskrift Wilhelm Lilljeborg tillegnad på hans åttionde födelsedag af Svenska Zoologer: 179-212, Almqvist \& Wiksells, Uppsala. http://dx.doi. org/10.5962/bhl.title.8413

Aurivillius C.W.S. 1899. Animalisches Plankton aus dem Meere zwischen Jan Mayen - Spitzbergen - K. Karls Land und der Nordküste Norwegens. Kongliga Svenska Vetenskaps-akademiens Handlingar 32 (6): 1-71.

Beliaev G.M. 1989. Deep-sea ocean trenches and their fauna. Nauka Publishing House, Moscow.

Beyer F. 1959. A new, bottom-living trachymedusa from the Oslofjord. Description of the species, and a general discussion of the life conditions and fauna of the fjord deeps. Nytt Magasin for Zoologi 6: $121-143$.

Bernstein T. 1934. Zooplankton des nördlichen Teiles des Karischen Meeres. Trudy Arkticheskogo nauchno-issledovaniya Instituta (= Transactions of the Arctic Institute) 9: 3-58.

Bigelow H.B. 1909. Coelenterates from Labrador and Newfoundland, collected by Mr. Owen Bryant from July to October, 1908. Proceedings of the United States National Museum 37 (1706): 301-320. http://dx.doi.org/10.5479/si.00963801.37-1706.301

Bigelow H.B. 1913. Medusae and Siphonophorae collected by the U.S. Fisheries steamer "Albatross" in the northwestern Pacific, 1906. Proceedings of the Unites States National Museum 44 (1946): 1-119. http://dx.doi.org/10.5479/si.00963801.44-1946.1

Boero F. \& Bouillon J. 1993. Zoogeography and life cycle patterns of Mediterranean hydromedusae (Cnidaria). Biological Journal of the Linnean Society 48: 239-266. http://dx.doi.org/10.1006/ bij1.1993.1017

Bouillon J. 1985. Essai de classification des Hydropolypes-Hydroméduses (Hydrozoa-Cnidaria). IndoMalayan Zoology 1: 29-243.

Bouillon J. 1993. Classe des Hydrozoaires. In: Doumenc D. (ed) Traité de Zoologie. Anatomie, Systématique, biologie. Tome III. Cnidaires. Cténaires. Fascicule 2. Masson, Paris.

Bouillon J. \& Boero F. 2000. Phylogeny and classification of Hydroidomedusae. Synopsis of the families and genera of the Hydroidomedusae of the world, with a list of the worldwide species. Thalassia Salentina 24: 47-296.

Bouillon J., Pagès F. \& Gili J.M. 2001. New species of benthopelagic hydromedusae from the Weddel Sea. Polar Biology 24: 839-845. http://dx.doi.org/10.1007/s003000100289

Bouillon J., Gravili C., Pagès F., Gili J.M. \& Boero F. 2006. An introduction to Hydrozoa. Mémoires du Muséum national d'Histoire naturelle 194, Muséum national d'Histoire naturelle, Paris. http://dx.doi. org/10.1086/586983

Bouillon J., Medel M.D., Pagès F., Gili J.M., Boero F. \& Gravili C. 2004. Fauna of the Mediterranean Hydrozoa. Scientia Marina 68 (Suppl. 2): 5-438. http://dx.doi.org/10.3989/scimar.2004.68s25

Bouillon J., Pagès F., Gili J.M., Palanques A., Puig P. \& Heussner S. 2000. Deep-water Hydromedusae from the Lacaze-Duthiers submarine canyon (Banyuls, northwestern Mediterranean) and description of two new genera, Guillea and Parateclaia. Scientia Marina 64 (Suppl. 1): 87-95. http://dx.doi. org/10.3989/scimar.2000.64s187 
Broch H. 1907. Hydroiden und Medusen. In: Brøgger T.O. (ed.) Report of the Second Norwegian Arctic Expedition in the "Fram" 1898-1902. 2 (12): 1-12. Videnskabs-Selskabet i Kristiania, Oslo. http:// dx.doi.org/10.5962/bhl.title.55607

Broch H. 1929. Craspedote Medusen. Teil II: Trachylinen (Trachymedusen und Narcomedusen). Nordisches Plankton 12: 481-539.

Browne E.T. 1903. Report on some medusae from Norway and Spitzbergen. Bergens Museum Arbog 1903: 1-36.

Chen Y., Lin Y., Zheng L. \& Cao W. 2015. The assemblage and abundance distribution of jellyfish in northern Beibu Gulf. Acta Ecologica Sinica 35 (10): 3382-3393. http://dx.doi.org/10.5846/ $\underline{\text { stxb201307011812 }}$

Chiu S.Y. 1954. Studies on medusae fauna of south-eastern China coast, with notes on their geographical distribution. Acta Zoologica Sinica 6 (1): 49-57.

Collins A.G., Bentlage B., Lindner A., Lindsay D., Haddock S.H.D., Jarms G., Norenburg J.L., Jankowski T. \& Cartwright P. 2008. Phylogenetics of Trachylina (Cnidaria: Hydrozoa) with new insights on the evolution of some problematical taxa. Journal of the Marine Biological Association of the United Kingdom 88 (8): 1673-1685. http://dx.doi.org/10.1017/S0025315408001732

Dunbar J.W. 1942. Marine macroplankton from the Canadian Eastern Arctic. II. Medusae, Siphonophorae, Ctenophora, Pteropoda and Chaetognatha. Canadian Journal of Research (D) 20 (3): 71-77. http:// dx.doi.org/10.1139/cjr42d-008

Fewkes J.W. 1888. Medusae. Appendix No. 132. Report on the Proceedings of the United States Expedition to Lady Franklin Bay, Grinell Land 2: 39-45. http://dx.doi.org/10.5962/bhl.title.56929

Foerster R.E. 1923. The Hydromedusae of the West coast of North America, with special reference to those of the Vancouver Islands Region. Contributions to Canadian Biology, n. ser. 1 (12): 219-277. http://dx.doi.org/10.1139/f22-012

Galea H.R. 2007. Hydroids and hydromedusae (Cnidaria: Hydrozoa) from the fjords region of southern Chile. Zootaxa 1597: 1-116.

Gili J.M., Bouillon J., Pagès F., Palanques A. \& Puig P. 1999. Submarine canyons as habitats of prolific plankton: three new deep-sea Hydroidomedusae in the western Mediterranean. Zoological Journal of the Linnean Society 125: 313-329. http://dx.doi.org/10.1006/zjls.1997.0107

Gili J.M., Bouillon J., Pagès F., Palanques A., Puig P. \& Heussner S. 1998. Origin and biogeography of the deep-water Mediterranean hydromedusae including the description of two new species collected in submarine canyons of Northwestern Mediterranean. Scientia Marina 62 (1-2): 113-134. http://dx.doi. org/10.3989/scimar.1998.62n1-2113

Gili J.M., Pagès F., Bouillon J., Palanques A., Puig P., Heussner S., Calafat A., Canals M. \& Monaco A. 2000. A multidisciplinary approach to the understanding of hydromedusan populations inhabiting Mediterranean submarine canyons. Deep Sea Research Part I: Oceanographic Research Papers 47: 1513-1533. http://dx.doi.org/10.1016/S0967-0637(99)00119-3

Grönberg G. 1898. Die Hydroid-Medusen des arktischen Gebiets. Zoologische Jahrbücher. Abteilung für Systematik, Geographie und Biologie der Tiere 11 (5): 451-468.

Haeckel E. 1879. Das System der Medusen. Erster Theil einer Monographie der Medusen. Mit einem Atlas von vierzig Tafeln. Gustav Fisher, Jena. http://dx.doi.org/10.5962/bhl.title.46856 
GALEA H.R. et al., Glaciambulata neumayeri gen. et sp. nov., a new Antarctic trachymedusa

Haeckel E. 1881a. Monographie der Medusen. Zweiter Theil. Erste Hälfte: Die Tiefsee-Medusen der Challenger-Reise. Zweite Hälfte: Der Organismus der Medusen. Gustav Fischer, Jena. http://dx.doi. org/10.5962/bhl.title.46856

Haeckel E. 1881b. Report on the deep-sea medusae dredged by H.M.S. Challenger, during the years 1873-1876. Report on the Scientific Results of the Voyage of H.M.S. Challenger during the years 187376, Zoology 4 (2): 1-154. http://dx.doi.org/10.5962/bhl.title.6513

Hesthagen I.H. 1971. On the biology of the bottom-dwelling Trachymedusa Tesserogastria musculosa Beyer. Norwegian Journal of Zoology 19 (1): 1-19.

Hosia A., Stemmann L. \& Youngbluth M. 2008. Distribution of net-collected planktonic cnidarians along the northern Mid-Atlantic Ridge and their associations with the main water masses. Deep Sea Research Part II: Tropical Studies in Oceanography 55 (1-2): 106-118. http://dx.doi.org/10.1016/j. dsr2.2007.09.007

Jamieson A. 2015. The hadal zone: life in the deepest oceans. Cambridge University Press, Cambridge.

Kramp P.L. 1914. Meduser og Siphonophorer. In: Conspectus faunae Groenlandicae. Meddelelser om Grønland 23: 381-456.

Kramp P.L. 1942. Medusae. In: The Godthaab Expedition, 1928. Meddelelser om Grønland 81 (1): $1-168$.

Kramp P.L. 1943. Medusae, Siphonophora, and Ctenophora. In: The Zoology of East Greenland. Meddelelser om Grønland 121 (12): 1-20.

Kramp P.L. 1947. Medusae. III. Trachylina and Scyphozoa. Danish Ingolf Expedition 5D (14): 1-66.

Kramp P.L. 1955. A revision of Ernst Haeckel's determinations of a collection of Medusae belonging to the Zoological Museum of Copenhagen. In: Papers in marine Biology and Oceanography. Deep-Sea Research 3 (Suppl.): 149-168. http://dx.doi.org/10.1002/qj.49708235329

Kramp P.L. 1957. Hydromedusae from the Discovery collections. "Discovery" Reports 29: 1-128. http://dx.doi.org/10.5962/bhl.part.12484

Kramp P.L. 1959. The hydromedusae of the Atlantic Ocean and adjacent waters. Dana Report 46: 1-283.

Kramp P.L. 1961. Synopsis of the medusae of the world. Journal of the Marine Biological Association of the United Kingdom 40: 1-469. http://dx.doi.org/10.1017/S0025315400007347

Kramp P.L. 1968. The hydromedusae of the Pacific and Indian Oceans. Sections II and III. Dana Report 72: $1-200$.

Kramp P.L. \& Damas D. 1925. Les Méduses de la Norvège. Introduction et partie spéciale. Videnskabelige Meddelelser fra dansk Naturhistorisk Forening i Kjøbenhavn 80: 217-323.

Langhorne P.J., Hughes K.G., Gough A.J., Smith I.J., Williams M.J.M., Robinson N.J., Stevens C.L., Rack W., Price D., Leonard G.H., Mahoney A.R., Haas C. \& Haskell T.G. 2015. Observed platelet ice distribution in Antarctic sea ice: An index for ocean-ice shelf heat flux. Geophysical Research Letters 42: 5442-5451. http://dx.doi.org/10.1002/2015g1064508

Larson R.J. \& Harbison G.R. 1990. Medusae from McMurdo Sound, Ross Sea including the descriptions of two new species, Leuckartiara brownei and Benthocodon hyalinus. Polar Biology 11: 19-25. http:// dx.doi.org/10.1007/bf00236517

Larson R.J., Mills C.E. \& Harbison G.R. 1991. Western Atlantic midwater hydrozoan and scyphozoan medusae: in situ studies using manned submersibles. Hydrobiologia 216/217: 311-317. http://dx.doi. org/10.1007/bf00026480 
Larson R.J., Matsumoto G.I., Madin L.P. \& Lewis L.M. 1992. Deep-sea benthic and benthopelagic medusae: recent observations from submersibles and a remotely operated vehicle. Bulletin of Marine Science 51 (3): 277-286.

Levinsen G.M.R. 1893. Meduser, Ctenophorer og Hydroider fra Grønlands Vestkyst, tilligemed Bemaerkninger om Hydroidernes Systematik. Videnskabelige Meddelelser fra dansk Naturhistorisk Forening i Kjøbenhavn (5) 4: 143-212.

Lindsay D.J. \& Miyake H. 2009. A checklist of midwater cnidarians and ctenophores from Japanese waters - species sampled during submersible surveys from 1993-2008 with notes on their taxonomy. Kaiyo Monthly 41 (8): 417-438.

Lindsay D. \& Pagès F. 2010. Voragonema tatsunoko (Trachymedusae: Rhopalonematidae), a new species of benthopelagic medusa, host to the hyperiid amphipod Mimonectes spandli (Physosomata: Mimonectidae). Zootaxa 2671: 31-39.

Linko A.K. 1904. Zoologische Studien im Barents-Meere. Auf Grund der Untersuchungen der wissenschaftlichen Murman-Expedition. Zoologischer Anzeiger 28 (6): 210-220.

Linko A.K. 1913. Zooplankton' Sibirskogo ledovitago okeana po sboram' russkoĭ polyarnor̆ ekspeditsii 1900-1903 g. Zooplancton de la Mer Glaciale de Sibérie après les récoltes de l'Expédition Polaire Russe en 1900-1903. Zapiski Imperatorskoĭ akademïi nauk (= Mémoires de l'Académie des Sciences de SaintPetersbourg) 29 (4): 1-53.

Maas O. 1893. Die craspedoten Medusen der Plankton-Expedition. Ergebnisse der in dem Atlantischen Ocean von Mitte Juli bis Anfang November 1889 ausgeführten Plankton-Expedition der HumboldtStiftung 2 (K): 1-17. http://dx.doi.org/10.5962/bhl.title.2167

Maas O. 1906a. Die arktischen Medusen (ausschließlich der Polypenmedusen). Fauna Arctica 4 (3): 479-526.

Maas O. 1906b. Medusen. In: Résultats du voyage du S.Y. Belgica en 1897-1898-1899 sous le commandement de A. de Gerlache de Gomery. Rapports Scientifiques, Zoologie 9 (21): 1-32. http:// dx.doi.org/10.5962/bhl.title. 2170

Mackie G.O. 1985. Midwater macroplankton of British Columbia studied by submersible PISCES IV. Journal of Plankton Research 7 (6): 753-777. http://dx.doi.org/10.1093/plankt/7.6.753

Mahuzier S. \& Sylvestre J.P. 2016. Cap sur le grand continent blanc. Quae, Versailles.

Mayer A.G .1910. Medusae of the world. Vol. II. The hydromedusae. Carnegie Institution of Washington Publication 109: 231-498. http://dx.doi.org/10.5962/bhl.title.5996

Minemizu R., Kubota S., Hirano Y. \& Lindsay D.J. 2015. A photographic guide to the jellyfishes of Japan. Heibonsha, Tokyo.

Miyake H., Lindsay D.J. \& Kubota S. 2004. Midwater and bentho-pelagic animals on the south slope of Shiribeshi Seamount off the west coast of Hokkaido. JAMSTEC Journal of Deep Sea Research 24: $37-42$.

Naumov D.V. 1956. [Medusae in the far eastern waters of the Soviet Union]. Trudy Problemnykh $i$ tematicheskikh soveshchanii (=Transactions of Special Problems Conferences) 6: 36-41.

Naumov D.V. 1969. Hydroids and Hydromedusae of the USSR. Israel Program for Scientific Translation, Jerusalem.

Naumov D.V. 1971. Gydroidnye i stsifoidnye medusy iz Kurilo-Kamchatskogo zhelova (Hydromedusae and Scyphomedusae from the Kurile-Kamchatka Trench). Trudy Instituta Okeanologii 92: 9-17. 
GALEA H.R. et al., Glaciambulata neumayeri gen. et sp. nov., a new Antarctic trachymedusa

Pagès F., Corbera J. \& Lindsay D. 2007. Piggybacking pycnogonids and parasitic narcomedusae on Pandea rubra (Anthomedusae, Pandeidae). Plankton and Benthos Research 2 (2): 83-90. http://dx.doi. org/10.3800/pbr.2.83

Panteleeva N.N., Frolova E.A. \& Sheiko O.V. 1999. New records of the benthic medusa Ptychogastria polaris Allman, 1878 (Trachylida, Hydroidea) in the Barents Sea and off the Kurile Islands (Pacific Ocean). Polar Biology 22: 372-378. http://dx.doi.org/10.1007/s003000050431

Picard J. 1955. Nouvelles recherches sur les hydroméduses des herbiers méditerranéens de posidonies. Recueil des Travaux de la Station Marine d'Endoume 15: 59-71.

Rees W.J. 1953. Records of hydroids and medusae taken at Herdla, Bergen in 1937. Universitetet $i$ Bergen. Arbok, 1952, Naturvitenskapelig Rekke 16: 1-8.

Russell F.S. 1980. Trachymedusae. Families: Geryonidae, Ptychogastriidae, Halicreatidae. Fiches d'Identification du Zooplancton 164: 1-4.

Runnström S. 1932. Eine Uebersicht über das Zooplankton des Herdla- und Hjeltefjordes. Bergens Museum Årbog 1931 (7): 1-67.

Sirenko B.I., Markhaseva E.L., Buzhinskaya G.N., Golikov A.A., Menshutkina T.V., Petryashov V.V., Semenova T.N., Stepanjants S.D. \& Vassilenko S.V. 1996. Preliminary data on suprabenthic invertebrates collected during the RV Polarstern cruise in the Laptev Sea. Polar Biology 16: 345-352. http://dx.doi. org//10.1007/BF02342182

Stepanjants S.D. 1989. Hydrozoa of the Eurasian Arctic Seas. In: Herman Y. (ed) The Arctic Seas: 397-430. Van Nostrand Reinhold, New York.

Stepanjants S.D. 2007. Conception of the bipolar distribution of the organisms: origin and modern views, on the Medusozoa example. Problemy Arktiki i Antraktiki 77: 89-96.

Stepanjants S., Coretese G., Kruglikova SB. \& Bjørklund K.R. 2006. A review of bipolarity concepts: history and examples from Radiolaria and Medusozoa (Cnidaria). Marine Biology Research 2 (3): 200241. http://dx.doi.org/10.1080/17451000600781767

Stübing D. \& Piepenburg D. 1998. Occurrence of the benthic trachymedusa Ptychogastria polaris Allman, 1878 (Cnidaria: Hydrozoa) off Northeast Greenland and in the northern Barents Sea. Polar Biology 19: 193-197. http://dx.doi.org//10.1007/s003000050234

Tanasijčuk N. 1927. Zoologische Ergebnisse der Terminalfahrt bis zum $75^{\circ} \mathrm{n}$ Br. Längs des KolaMeridians (Barents-Meer) in August, 1925. Dokladi Akademii Nauk USSR 1927: 359-363.

Thiel M.E. 1932a. Uebersicht über die Hydromedusen der Arktis. Fauna Arctica 6 (2): 121-158.

Thiel M.E. 1932b. Die Hydromedusen-Fauna des Nördlichen Eismeeres in tiergeographischer Betrachtung. Archiv für Naturgeschichte, n. ser. 1 (3): 435-514.

Thuesen E.V. 1993. Vampyrocrossota childressi, a new genus and species of black medusa from the bathypelagic zone off California (Cnidaria: Trachymedusae: Rhopalonematidae). Proceedings of the Biological Society of Washington 106 (1): 190-194.

Thuesen E.V. 2003. Crossota millsae (Cnidaria: Trachymedusae: Rhopalonematidae), a new species of viviparous hydromedusa from the deep sea off California and Hawaii. Zootaxa 309: 1-12.

Vanhöffen E. 1902. Die craspedoten Medusen der deutschen Tiefsee-Expedition 1898-1899. I. Trachymedusen. Wissenschaftliche Ergebnisse der deutschen Tiefsee-Expedition 1898-1899 3: 55-86.

Vanhöffen E. 1912. Die craspedoten Medusen der deutschen Südpolar-Expedition. Deutsche SüdpolarExpedition 1901-1903, Zoologie 5 (3): 351-396. 
Vibe C. 1950. The marine mammals and the marine fauna in the Thule district (Northwest Greenland) with observations on ice conditions in 1933-41. Meddelelser om Grønland 150 (6): 1-116.

Yashnov V.A. 1940. Hydromedusy Sibirskogo poberezh'ya Ledovitogo Okeana (Hydroméduses de l'Océan glacial de Sibérie). Biulleten 'Moskovskogo Obshchestva Ispytatelei Prirody (= Bulletin de la Société Impériale des Naturalistes de Moscou, section Biologie), n. ser. 48 (2-3): 107-114.

Yashnov V.A. 1948. Hydromedusae - Gidroidnye medusy. In: N.S. Gaevskoi M.S. (ed) Opredelitel' fauny i flory severnykh morei SSSR: 65-74, State Publishing House for Soviet Science, Moscow.

Zeidler W. 2012. A review of the hyperiidean families Mimonectidae and Proscinidae (Crustacea: Amphipoda: Hyperiidea: Scinoidea). Zootaxa 3533: 1-74.

Manuscript received: 23 April 2016

Manuscript accepted: 4 July 2016

Published on: 20 December 2016

Topic editor: Rudy Jocqué

Desk editors: Jeroen Venderickx \& Kristiaan Hoedemakers

Printed versions of all papers are also deposited in the libraries of the institutes that are members of the EJT consortium: Muséum national d'Histoire naturelle, Paris, France; Botanic Garden Meise, Belgium; Royal Museum for Central Africa, Tervuren, Belgium; Natural History Museum, London, United Kingdom; Royal Belgian Institute of Natural Sciences, Brussels, Belgium; Natural History Museum of Denmark, Copenhagen, Denmark; Naturalis Biodiversity Center, Leiden, the Netherlands. 